\title{
ETHNIC DIVERSITY AND GROWTH: REVISITING THE EVIDENCE *
}

\author{
José G. Montalvo \\ UPF, BARCELONA GSE AND IPEG \\ MARTA REYNAL-QUeROL \\ ICREA-UPF, BARCELONA GSE AND IPEG
}

The relationship between ethnic heterogeneity and economic growth is complex. Empirical research working with cross-country data finds a negative, or statistically insignificant, relationship. However, research at the city level usually finds a positive relationship between diversity and wages/productivity. Generally, the trade-off between the economic benefits of diversity and the costs of heterogeneity implies that the relationship between diversity and growth depends on the size of the area used as the unit of observation. In this paper we perform a systematic analysis of the effect of

*We would like to thank Daron Acemoglu, Alberto Alesina, Tim Besley, Klaus Desmet, Ruben Durante, Oded Galor, Saumitra Jha, Massimo Morelli, Gerard Padro, Elias Papaioannou, Luigi Pascali, Felipe Valencia, Hans-Joachim Voth, and especially, Antonio Ciccone, Stelios Michalopoulos and Roman Wacziarg for their helpful comments. We also thank the participants in the Bocconi Workshop on Conflict, the Meeting of the European Public Choice Society, the EPCS of Groningen, the Berlin Workshop on Advances on the Political Economy of Conflict and Redistribution III, the Invited Session on Political Economy of Development at the EEA Meetings of 2015 in Mannheim, the Yale University Workshop on The Political Economy of Social Conflict, and the NBER Summer Institute. We have also benefited from the comments of participants in seminars at Stanford GSB, Oxford, LSE, Warwick, Bonn, Stockholm, UPF and CREI. Financial support from the European Research Council (ERC), the Spanish National Science Foundation, and the Government of Catalonia is gratefully acknowledged. We would like to thank the financial support from the Spanish Ministry of Economy and Competitiveness, through the Severo Ochoa Programme for Centres of Excellence in R\&D (SEV-2015-0563). 
the size of geographical units on the relationship between ethnic diversity and growth. We find a positive relationship for small geographical areas and no effect for large areas and countries. There are potentially different mechanisms that can explain this result depending on the structure of the economy and its level of development. In the case of Africa, we argue that a possible explanation of the positive relationship between diversity and growth is the increase in trade at the boundaries between ethnic groups due to ethnic specialization. 


\section{INTRODUCTION}

The issue of the effect of ethnic diversity on economic development has generated a large body of literature (see Alesina and La Ferrara, 2005, for a review). Cross-country regressions generally show a negative effect of heterogeneity on development. These findings have supported the view that Africa's 'growth tragedy' is the result of its high degree of ethnic diversity (Easterly and Levine, 1997). By contrast, research based on data from small geographical areas, such as cities, frequently finds a positive effect of diversity on wages or productivity.

This paper develops a systematic strategy to study the effect of diversity on growth by analyzing this relationship at different spatial scales. Previous research has typically relied on political and/or administrative frontiers, or cities/SMA boundaries, to define the unit of analysis. Our analysis instead considers the grid-country cell as the basic units of observation. This definition is convenient since our objective is to analyze the effect of sequentially increasing the size of the grid setting up to country-size.

At the highest level of resolution of the grid there is obviously no possibility of finding measures of output, value added, or even wages for most countries. We consequently take advantage of luminosity data to proxy for local economic activity $^{1}$. Recent research has shown that light density at night is a good proxy of economic activity. We find that, at the highest degree of resolution, there is a positive association between ethnic heterogeneity and economic growth. Finding this correlation at the country level does not, however, resolve the issue of endogeneity caused by the possibility that other unobserved characteristics can drive the association via, for instance, institutional differences. Using artificially constructed cells mitigates this concern. In addition, the results are robust to a large number of potential issues. First, we show that the results are unaffected

1. See, for example, Chen and Northaus,(2011) or Pinkowskiy and Sala-i-Martin, (2016) 
by the use of a large number of controls to account for within-country variation, such as geography, climate, soil quality, proximity to lakes or political capitals, etc. Second, we run one hundred different regressions randomly changing the initial location of the point that defines, together with the level of resolution, the exact location of the area covered by each cell. The results are robust to the location of the origin of the grid that defines the cells. Third, we show that the positive effect of heterogeneity on economic growth is not due to urban area, nor is it simply capturing an agglomeration effect. Finally, we show that reducing the degree of resolution of the grid decreases the association between ethnic diversity and development, to the point of finding no association between heterogeneity and development.

These findings likely derive from different mechanisms, depending on the sectoral structure of the economy or its level of development. In particular, we consider the case of Africa. In order to understand why regional development is faster along ethnic borders, we propose a mechanism related to trade. We find that those areas which have more ethnic diversity, also have a higher proportion of markets. Previous research (Michalopoulos, 2012) has shown that ethnic groups in Africa typically specialize in different agricultural products and therefore have incentives to exchange goods. Ethnic groups that are geographically close to one another may therefore have a large volume of trade despite their different ethnic origins. In order to provide evidence of this potential mechanism, we show that local markets in Africa are located close to ethnic borders, supporting this interpretation.

The structure of the paper is as follows. Section 2 discusses the literature on the economic effects of ethnic heterogeneity on development and the contributions of the paper. Section 3 describes the data. Section 4 presents the basic results and discusses some exercises that show the robustness of the results. 
Section 5 discusses the effect of changing the degree of geographical resolution of the grid. Section 6 proposes a mechanism and presents some supporting evidence. Section 7 concludes.

\section{Diversity AND Growth}

Is ethnic diversity good or bad for economic development? The literature has often emphasized the trade-off between the benefits of diversity and the costs of heterogeneity. On the one hand, ethnic diversity can be beneficial by enhancing productivity through innovation, skill complementarities, or increased creativity, trade, and product variety. On the other hand, diversity can generate an inefficient provision of public goods, ethnically biased policies, and conflict or disagreement over common public goods and policies. All of these theories generally imply that there is a size at which benefits and costs are equalized, implying that on a smaller scale we should find a positive effect of ethnic diversity and on a larger scale we should find a negative effect. In order to analyze the relative importance of the costs and benefits of ethnic diversity, the literature has adopted two alternative approaches.

One approach is to analyze the endogenous formation of jurisdictions (number, size, and shape), modeling the optimal trade-off between the benefits of diversity and the costs of heterogeneity to determine its equilibrium size. Along these lines, Alesina and Spolaore (1997) focus on the tension between the benefits of large jurisdictions and the costs of population heterogeneity, while Alesina and La Ferrara (2005) propose a model with a positive effect of variety in the production function and a decreasing utility of public goods as population heterogeneity increases.

A second approach used in the literature on the relationship between ethnic diversity and growth, conflict, or the quality of institutions takes as given the 
definition of a particular type of jurisdiction: countries, regions, counties, cities, and even villages or schools districts. However, theoretical models on the effects of ethnic diversity on economic development are mostly agnostic about the scale of analysis. Yet the problem of scale plays a central role in many sciences like, for instance, applied ecology. There is no single natural scale at which ecological phenomena should be studied. In physics, while we wait for a unifying theory, there is a clear distinction between laws at the macroscopic level, for which classical mechanics rules, and the microscopic level, for which quantum mechanics describes the behavior of fundamental particles ${ }^{2}$. Although theoretical models are silent about scale of analysis in the relationship between ethnic diversity and development, all the models point in one direction: if there is a positive effect of ethnicity it is more likely to be observed for a small geographical unit. In this paper we analyze the effect of ethnic heterogeneity as we increase the size of the geographical units of analysis. We begin with a country cell as the unit of observation, and analyze the effect of increasing its size up to borders with other countries. The size of the initial units is, in general, smaller than regions and larger than cities. This empirical strategy allows us to systematically study the impact of ethnic heterogeneity on development for different levels of geographical aggregation.

To date, the empirical analysis of the effect of ethnic diversity on economic development has relied on units of analysis based mostly on political jurisdictions. Initially the literature analyzed the issue by running cross-country regressions. For example, using cross-country differences in ethnic diversity, Easterly and Levine (1997) show that Africa's low level of economic development is associated with its high degree of ethnic heterogeneity. Alesina et al. (2003) and

2. At a deeper level, the issue of scale in physics becomes a question of the continuous nature of space-time versus the quantification of the atomic world. Quantum loop theory speculates that below the Plank length both space and time are discrete, although empirical evidence is still lacking. 
Alesina and La Ferrara (2005), also using cross-country data, similarly show a consistent negative effect of ethnic fractionalization on growth. Further research has qualified the conditions for this negative relationship. For instance, Collier (2001) finds that ethnic diversity only has a negative effect on growth in nondemocratic situations. In the same spirit, Easterly (2001) finds that when ethnic diversity is high, poor institutions have an even more adverse effect on growth and policy. In countries with sufficiently good institutions, however, ethnic diversity does not reduce growth or worsen economic policies. Good institutions also reduce the risk of wars and genocides that may otherwise result from ethnic fractionalization. Alesina and La Ferrara (2005) argue that heterogeneity has a more negative effect when income level is low. Alesina, Spolaore, and Wacziarg (2000) find that the effects of country-size on economic success is mediated by the extent of freedom of trade. Montalvo and Reynal-Querol (2005) show that ethnic diversity has a direct negative effect on growth, while ethnic polarization has an substantial indirect effect through the reduction of the rate of investment and the increase in the likelihood of conflicts ${ }^{3}$.

However, most city level studies find that heterogeneity has a positive effect on indicators such as wages or productivity. ${ }^{4}$ Ottaviano and Peri (2005) find that US born individuals pay higher rents in heterogeneous cities, which implies that diversity has a positive effect on the production and consumption of amenities. Ottaviano and Peri (2006) find that, on average, cultural diversity has a net positive effect on the productivity of US-born citizens. Sparber (2010) also finds a positive relationship between racial diversity and wages across US

3. Recently, Gören (2014) found similar results using a larger dataset of countries. He also finds an indirect positive effect of ethnic diversity through international trade.

4. Studies at higher levels of aggregation, or those analyzing variables different from wages at the city level, provide conflicting results. For instance, Dincer and Wang (2011) find a negative relationship between ethnic diversity and economic growth throughout Chinese provinces. Although ethnic diversity does not fully explain the growth differentials between Chinese coastal and inland provinces, the high level of ethnic diversity in inland China nevertheless appears to be an important factor. The city level research of Glaeser, Scheinkman and Shleifer (1995) show that racial heterogeneity does not have any effect on population growth. 
cities. ${ }^{5}$ Lee (2011) uses data on growth in employment for 53 English cities for the period 1981-2001 to show that cities with more diverse populations have grown faster, but that it is diversity of country of birth rather than diversity of ethnicity that drives this effect. For the period 1991-2001, neither diversity by country of birth nor ethnic diversity are significant. Yet when variables accounting for both are included together, the cities with a large number of migrants appear to experience higher employment growth in the 1990s, while ethnically diverse cities were less successful. Lee (2014) compares the effect of diversity at the firm level and city diversity. He finds a positive effect of diversity in firm owners on innovation but no relationship between the fractionalization by country of birth, at the county level, and firm level innovation. More recently, and using a novel approach, Alesina, Harnoss, and Rapoport (2016) find that diversity of immigration relates positively to measures of economic prosperity.

The literature has thus generally found that diversity seems to be negative, or irrelevant, for development at high levels of aggregation, but positive at low levels of geographical aggregation, such as the city level. The growing availability of geographically detailed information on economic variables, and the recent focus on small units of analysis, make the issue of aggregations very relevant. This level of detailed geographical data is, in fact, becoming increasingly popular in the analysis of ethnicity. Such studies have, for example, examined the relationship between ethnicity and institutions (Michalopoulos and Papaioannou, 2013, 2014), ethnicity and inequality (Alesina, Michalopoulos, and Papaioannou, 2016) and the origins of ethnolinguistic differences (Michalopoulos, 2012). Several papers have recently used the boundaries between ethnic groups to generate quasi-experiments to analyze the effect of national institutions on subnational development (Michalopoulos and Papaioannou, 2014) or the effect

5. Studies of other countries find similar results, such as that of Nathan (2011) for the case of the UK, Suedekum, Wolf and Blien (2014) for Germany, and Bakens, Mulder and Nijkamp (2013) for the Netherlands. 
of partitioned ethnicities on conflict (Michalopoulos and Papaioannou, 2016). Using the shape of the border to measure the artificiality of the boundaries, Alesina, Easterly and Matuszeski. (2011) show that the partition of ethnic groups is a significant determinant of GDP per capita.

In this paper, we present a systematic examination of the effect of ethnic diversity on economic growth using geographical units of increasing size, starting from very small cells and going up to the country level. We argue that the answer to the question of the nature of the relationship between ethnic heterogeneity and growth is different depending on the size of the unit of analysis. We find that when the unit of analysis is small (for instance, cells of one degree by one degree) there is a positive relationship between ethnic diversity and economic growth.

The literature has described several potential mechanisms that explain the positive effect of ethnic heterogeneity on development. Ethnic diversity at the city level is, for example, important for innovation and productivity. Another potential mechanism, which we explore in this paper, is based on the increase in trade due to the production specialization or service complementarities of different ethnic groups. The issue of the impact of spatial ethnic heterogeneity on intra-national trade is an underdeveloped topic of research. Aker et al. (2014) argue, using information from Niger, that transaction costs are higher for trade between regions with different ethnicities versus trade in homogeneous areas. It is well known that trust is higher among people of the same ethnic group and that this conequently reduces transaction costs. However, ethnic specialization in production generates a motive for trade that is absent within homogeneous groups. There are, in fact, many mitigating mechanisms that can reduce the cost of transactions with other ethnic groups. Several papers have analyzed mechanisms that can support trade among agents that belong to dif- 
ferent groups. For example, Glaeser (2005) argues that the demand of hatred depends on the costs and benefits of information about the out-group. Trade can deter the spread of hatred because it creates incentives of demand for correct information and reduces the cost of acquiring it. Greif $(1993,2000,2006)$ argues that exchange tends to be personal and supported by reputation in the early stages of development. In addition, if there is lack of trust among traders of different groups there is need for a monitoring mechanism that allows for trade. Geographical proximity simplifies monitoring activities. Jha (2013), for example, shows that South Asia's medieval ports were less prone to riots, even many years after colonization, despite being ethnically very diverse. Jha (2013) argues that this inertia was caused by the development of institutions that supported inter-ethnic exchange.

From a theoretical perspective, if we assume that ethnic specialization increases the variety of goods in the presence of ethnic diversity, it is simple to write down a growth model that depicts a positive relationship between growth and ethnic diversity. Assume output $\mathrm{Y}$ is produced using labor, and aggregate consumption is a CES composite of a variety of goods $\mathrm{N}$ which is a function of ethnic diversity $(\gamma)$

$$
\begin{aligned}
& C=\left(\int_{0}^{N} Y_{i}^{1 / \sigma} d i\right)^{\sigma} \\
& N=L^{(1+\gamma)}
\end{aligned}
$$

Assuming for simplicity that each intermediate good, $Y_{i}$, is used in the same quantity $\left(Y=Y_{i}\right)$ then the growth rate of per capita output is $g=\sigma(1+\gamma) n$ where $\mathrm{n}$ is the growth rate of labor. Ottaviano and Peri (2005) formulate a production function with non-tradable intermediate goods and taste for variety. Ottaviano and Peri (2006) describe a model where diversity enters the produc- 
tion function affecting total factor productivity. These approaches consider a fixed size area. The approach in Alesina and La Ferrara (2005) is better suited for the analysis of the relationship between heterogeneity and development as the size of the units of analysis changes. In their model, there is an optimal level of diversity determined by the trade-off between the benefits and the costs of ethnic heterogeneity. The larger the benefits from skill variety in production, the larger the size, while the higher the effect of heterogeneity on the unwillingness to share public goods, the smaller the size. Obviously the specific mechanism that explains the benefits and costs when ethnic heterogeneity increases may be different depending on the level of development and the sectoral structure of the economy. For instance, in developing countries, the benefits in production from the variety of skills are less relevant than in advanced societies.

\section{DATA}

The previous section shows that theoretical models balance the positive effects of diversity (skill complementarities, propensity to innovate, specialization and trading, etc.) with the negative effects (problems in the provision of public goods, potential conflict, etc.). The empirical literature generally finds that the negative effect of diversity prevails over the positive effect. This conclusion could, however, be the result of a measure of diversity that is not appropriate. For instance, Alesina, Harnoss and Rapoport (2016) argue that it is diversity of immigration, and not ethnic diversity, that is positively related to economic development at the cross-country level. In order to further analyze this issue, we follow a different strategy. From a theoretical perspective, it is clear that for small areas the positive effect of diversity should generally dominate the negative effect, while the opposite should be true for large geographical areas. In this paper we therefore investigate the effect of ethnic diversity on development 
using units of increasing size to investigate whether the sign of the relationship changes from positive to negative (null) as we increase the size of the units of analysis up to country size ${ }^{6}$. We interpret this strategy as a strategy to address the well-known modifiable areal unit problem (MAUP). In essence MAUP implies that the relationship between variables at one scale may be distorted when analyzed using another scale ${ }^{7}$. There are two distinct types of MAUP. The first concerns the scale at which one chooses to analyze the information, or the level of geographical aggregation. To address this issue, a finer scale than what is thought necessary should always be adopted or, even better, the question should be analyzed using different scales of observation. The second type of MAUP regards the so-called zone or grouping issue. More specifically, the choice of geographic grouping schemes or zones, even if all the units are all of the same scale, can affect the results. To address this issue, simple criterion can be used to generate the units, such as basic shapes of equal size. To further check the robustness of the results, the latter can be compared with the results of different schemes used to initially construct the cells.

These are strategies that we follow in the paper. Given that we need to begin with a high level of geographical resolution, and then progressively reduce the resolution, our unit of observation is grid-country cells that generate country level data at minimum resolution. We construct grids of decreasing resolution, and calculate the value of the explanatory variables and the outcome for each of these cells. We therefore perform the analysis using grids that generate increasingly larger units of observation (cells), beginning with half by half decimal degree cells and moving upwards towards larger sizes (two by two degree cells and four by four degree cells). Finally, we increase the size of our cells to the the country size so as to analyze the results using cross-country regressions.

6. This view is also compatible with the empirical findings detailed in the previous section.

7. See Gotway and Young (2002) for an interesting general overview on the issue of aggregating spatial data. 
We also check the robustness of the results by changing the origin of the grid that generates the country cells. The basic variables for the specification are measures of local growth and ethnic diversity ${ }^{8}$

\section{III.A. Local growth}

To measure growth in each cell we need information on economic development. At high levels of resolution it is difficult to find estimations of GDP and, certainly, many areas of the world do not have information on geocoded high-resolution measures of economic development. It has, however, become increasingly common to use satellite night light density as a proxy for local economic activity when working with small geographical areas. Satellite night light density data are available from the National Oceanic and Atmospheric Administration and have been used recently by scholars such as Henderson, Storeygard, and Weil (2012), Michalopoulos (2012), Michalopoulos and Papaioannou (2013, 2014), and Alesina, Michalopoulos, and Papaioannou (2016). There is also a series of papers that specifically corroborate a high within-country correlation between GDP and light density at night. Chen and Nordhaus (2011) find that luminosity has informational value for countries, regions, and areas with poor quality or missing data. They also argue that night light has a large estimated optimal weight in the estimation of growth rates in countries with low quality statistical systems, following the A to D classification of the Penn World Tables (PWT). In particular, the authors show that the weight is, in these cases, larger than in the estimation of the level of GDP per capita. The importance of night light, as measured by its weight, in the estimation of growth is always higher in low-GDP density countries than those of high-GDP density, for any

8. For a full description of the variables included in the empirical analysis see the Data Appendix. 
level of quality of the statistical system. ${ }^{9}$ More recently, Pinkovskiy and Sala-iMartin (2016) have used nighttime lights to show that national accounts are an excellent proxy for actual income, while survey means have very little, if any, informative content to estimate true income. They show that growth rates of GDP per capita are very highly correlated with the growth of night light per capita while the growth rate of survey means is very weakly correlated with the growth of night light per capita. Along similar lines, Jean et al. (2016) use satellite images and machine learning techniques to predict poverty at small scales. In their application, they use daytime satellite photos to capture details of the landscape (metal roof, water, etc.) that they correlate, using neural networks, with satellite night lights as a proxy for economic activity ${ }^{10}$.

All data was obtained from the National Geophysical Data Center, specifically the Earth Observation Group (EOG) reference to version 4 of the DMSPOLS Night-time Lights Time Series. The data is divided by year, from 1992 to 2013 and by six satellites from F10 to F18. From the three available image types, we use the stable light version, which is quantitized into 63 levels of light intensity. We have information on the Night Time Light and the total Night Time Light density by pixel from 1992 to 2010. Population data comes from the Gridded Population of the World. For each cell, we constructed measures of luminosity per capita. Our basic dependent variable is the per capita economic growth between 1992 and 2010.

9. The cross-validation analysis in Michalopoulos and Papaioannou (2013) shows that light density at night is highly correlated with a wealth index across households in four large African countries.

10. Night light intensity has also being used to measure inequality at low levels of geographical aggregation. See, for example, Alesina Michalopoulos, and Papaioannou (2016) and Montalvo and Reynal-Querol (2017) 


\section{III.B. Spatial Ethnic Diversity}

We use data from GREG (Geo-referencing of ethnic groups) for the geospatial location of ethnic groups (Weidman, Rod, and Cederman, 2010). Relying on maps and data drawn from the classical Soviet Atlas Narodov Mira (AnM), the GREG dataset employs geographic information systems (GIS) to represent group territories as polygons. The full GREG dataset has global coverage and consists of 929 groups. ${ }^{11}$

For each country cell, we construct two types of measures of diversity. For the first measure, we use the percentage of territory that the homeland of the ethnic group covers in a particular cell. The second measure uses the percentage of the population living in the homeland of the ethnic group in a particular cell. We use the traditional fractionalization measure (Herfindhal index). Since data on population living in the specific homeland of a cell-country unit can only be computed from 1990 on, we use this second measure as a robustness check. Diagram 1 shows, using the example of a cell in Cameroon, the distribution of ethnic groups as well as the proportion of each group relative to the larger population, and the area of the cell.

To capture ethnic diversity we also use the Ethnolingustic Fractionalization Index (ELF). In particular the index takes the form,

$$
F R A C=1-\sum_{i=1}^{N} \pi_{i}^{2}=\sum_{i=1}^{N} \pi_{i}\left(1-\pi_{i}\right)
$$

where $\pi$ is the proportion of people who belong to ethnic group i. The broad popularity of the ELF index is based on its intuitive appeal: the index captures

11. Desmet, Ortuño-Ortin, and Wacziarg (2012) use a linguistic tree to calculate measures of diversity at different levels of aggregation. They argue that, while deep cleavages are relevant for conflict, more superficial cleavages are relevant for economic growth. We tend to agree with this conclusion, although given the computational challenges of the exercises in this paper, an analysis of that incorporates the degree of ethnic cleavages must necessarily be left for a future project. 
the probability that two randomly selected individuals from a given country will not belong to the same ethnolinguistic group ${ }^{12}$.

\section{Basic Results}

The basic specification is

$$
\ln y_{i j t}-\ln y_{i j 0}=\alpha_{j}+\beta \ln y_{i j 0}+\gamma F R A C_{i j}+\sum \gamma_{k} z_{k i j}+\epsilon_{i j}
$$

where $i$ and $j$ refer to a cell and a country respectively, and $y_{i j t}$ and $y_{i j 0}$ are night light per capita in 2010 and 1992 respectively ${ }^{13}$. FRAC is the level of ethnic fractionalization at each country-cell. Using this arbitrary geographical area (one by one degree cells), we minimize concerns over the possible endogeneity of the political boundaries highlighted in the cross-sectional empirical literature. We also include controls for geographic and climate variables. To control for other factors that are country-specific, we include fixed effects. This is another advantage with respect to cross-country regressions. In fact, when we increase the size of the country-cells we ultimately reach the size of each country and, therefore, can analyze the impact of the border versus the effect of the size of the cell ${ }^{14}$.

Table 1 shows the basic results. Columns 1 to 3 include all the observations. ${ }^{15}$ Column 1 presents the outcome of the regression without geographical and climate controls, and without country fixed effects. The estimation shows

12. The Data Appendix describes in detail the sources of the variables used in the empirical exercises.

13. The measure of night light per capita is adopted as the best proxy for GDP per capita. Pinkovskiy and Sala-i-Martin (2016) similarly use night light per capita in all of their baseline regressions.

14. This procedure implies that the size of the country determines the largest cell of the area of each particular country. Since there are many more cells than countries, this effect is not likely to be relevant.

15. For cells that are not populated we use the transformation in Michalopoulos and Papaioannou (2014). See Data Appendix. 
a positive relationship between ethnic fractionalization and growth controlling for the initial level of development ${ }^{16}$. Column 2 includes country fixed effects. In this case we similarly find a positive effect of ethnic fractionalization on economic growth. This result is still found when we use robust standard errors clustered at country level (Column 3). ${ }^{17}$ Columns 4 to 6 reproduce the previous regressions but using only the cells that are populated. Column 4 does not include country fixed effects. Column 5 includes country fixed effects and column 6 presents the results using a robust standard error clustered at country level ${ }^{18}$.The positive association between ethnic fractionalization and growth is robust to using the sample of the populated areas. These results indicate that there is a positive relationship between local ethnic diversity and local growth at a very high degree of resolution. Using the results of the last column, an increase in the degree of ethnic heterogeneity of two standard deviations implies an annual increase of output per capita of 1.1 percentage points.

\section{IV.A. Controlling for observable variables}

Table 2 shows the results of the basic regression when we include many additional controls. ${ }^{19}$ Column 1 includes controls for geographic and climate controls to the specification in the last row of Table 1. The estimated coefficient implies that an increase in two standard deviations of ethnic heterogeneity increases average annual per capita growth by 1.3 percentage points ${ }^{20}$. Column

16. In the regressions of Table 1 the speed of convergence implied by the coefficient of the log of the initial level of development ranges from $1.6 \%$ to $2.4 \%$, values similar to those typically found for the speed of convergence across regions or countries. This result indicates that night light density generates similar results to the those found with other indicators of economic development.

17. The conclusion remains unaffected if we also use a correction for spatial correlation.

18. The standard errors corrected for spatial correlation using Conley's approach are shown between parenthesis.

19. See Data Appendix for a detailed description of each variable.

20. To relate this to GDP per capita, we note that Pinkovskiy and Sala-i-Martin (2016) cannot reject the null hypothesis that the weight of log GDP per capita is 1 in the optimal light night-based proxy of true income. The same result holds for the subsample of Africa. 
2 adds (logged) population density to the list of explanatory variables. Ethnic fractionalization continues to have a positive and significant effect on growth. ${ }^{21}$ In Column 3 we show that the results are not driven by the proportion of fertile soil or natural resources. Ethnic fractionalization still has a positive and significant effect on economic growth. Column 4 adds the distance to the closest river and the distance to the closest lake to the set of explanatory variables without affecting the basic message of the previous columns. Column 5 includes a dummy variable for country cells that contain part of the border of a country ${ }^{22}$. The basic result is also supported in this specification.

One interesting fact in Table 2 is that including population density does not affect the size of the coefficient on the effect of ethnic diversity on growth ${ }^{23}$. When using cross-country data, the high correlation between ethnic diversity and population density has an important effect on the estimation of the parameter associated with ethnic diversity. However, at the subnational level, the same is not supported by the data. The borders of ethnic homelands do not concentrate areas with higher/lower proportion of cities, or population density, than other areas. Many big cities, with high population density, are not located at these borders. We can show this result using three alternative illustrations. First, Figure 1 shows population distribution together with ethnic borders in the case of Africa. The darker areas are often found at the center of ethnic groups, illustrating that borders are not particularly more or less densely populated. Second, in Table 3 we list the cells by deciles, and compute the average ethnic diversity at different deciles of population density. The table shows a patternless situation: there is no clear correlation between ethnic fractionalization and population density. This descriptive evidence helps to understand why the

21. Population refers to the year 1990. Results are also robust to the inclusion of the $\log$ of population and area size.

22. Column 5 includes between parenthesis the standard error corrected by spatial correlation.

23. We indebted to Roman Wacziarg for suggesting this exercise. 
coefficient of ethnic diversity does not change when we introduce the variable of population density. Since what we measure is spatial diversity, based on the borders of ethnic homelands, this is not surprising.

In order to further explore the effect of population density on the relationship between ethnic diversity and economic growth, Table 4 analyses the interaction of both variables. In Column 1 we show that the effect of diversity on growth is higher in high density population areas. In Column 2 we use an alternative definition of densely populated area, which is proxied by urban areas. The dummy for urban agglomeration ${ }^{24}$ has value 1 if the city is the national capital, the provincial capital, or a urban agglomeration of more than 500,000 inhabitants. We also interact urban agglomeration with ethnic diversity. In this case the estimated parameters of the cross product is not statistically significant. Finally, in Columns 3 and 4 we construct yet another two alternative proxies for densely populated areas. The first dummy takes value 1 if the cell is on the 10 decile of highly densely populated, and zero otherwise. The second dummy takes value 1 if the cell is on the 20 decile of highly densley populated, and zero otherwise. Columns 3 and 4 show, respectively, the estimation using these two new measures of densely populated areas as well as their cross product with ethnic diversity. None of the estimated coefficient of these variables is statistically significant.

\section{IV.B. Addressing urban agglomeration and migration}

The positive relationship between ethnic diversity and local growth could simply be capturing an agglomeration effect related with the presence of large cities in the cell and, therefore, have a level of relationship different from the country cells that we use as the basic unit of observation. The empirical liter-

24. The next section discusses at length the issue of urban agglomeration. 
ature showing a positive impact of ethnic diversity on growth refers mostly to cities. Moreover, related to this "urban premium," cities have higher productivity and higher wages than other areas. Is it just the urban premium that drives our results? Table 5 addresses this issue. In Column 1 we include a dummy for the national capital while in Column 2 we also add dummies for provincial capitals. Column 3 adds dummies for urban agglomerations, considering as such urban areas with more than 500,000 inhabitants. In all the cases, the basic results of Tables 1 and 2 are maintained: ethnic diversity has a positive and significant effect on growth.

To continue investigating the issue of the influence of urban agglomeration, Columns 4 to 8 of Table 5 restrict the sample to different subsets of country cells without urban centers. Column 4 excludes the cells that contain an urban center. ${ }^{25}$ Columns 5 and 6 exclude the richest areas (upper $10 \%$ and $20 \%$ respectively) mostly associated with the presence of urban areas. The most densely populated cells are also associated with the presence of urban metropolitan areas. For this reason, Columns 7 and 8 present the estimation dropping from the sample the cells with the highest population density (upper 10\% and $20 \%$ respectively). Overall, the results of Table 5 indicate that the relationship between ethnic diversity and local growth are not driven by the agglomeration effect tied only to the presence of urban areas.

This exercise also addresses a potential measurement problem associated with the ethnic distribution of the population living in urban centers and, in particular, in capitals. Papaionnaou and Michalopoulos (2014) claims that, under the assumption that in a given urban center the respective indigenous group is relatively more populous than recent migrant groups, this should not be an important concern. We have shown in this section that our basic results 
are robust to the elimination of urban centers from the sample.

Finally, we check that our results are not an artifact of post-colonial migration to prosperous countries and subsequent increases in ethnic diversity in those areas. Following the strategy of Ashraf and Galor (2013), we perform the analysis restricting the sample to specific sets of countries: countries that do not belong to the OECD; non-Neo-European countries; non-Latin-American countries; non-Sub-Saharan African countries; all the previous. The results of Table 6 show that the relationship between diversity and growth is not driven by areas of the world that potentially experienced much post-1500 migration.

\section{IV.C. The influence of the grid generating coordinates}

Did we choose a "lucky" grid? It is unlikely that any initial coordinates could produce a lucky grid, as a large number of cells are generated. However, in this section we consider this possibility and produce 100 grids with random initial coordinates. More specifically, we take our initial coordinates (longitude -180; latitude -89) and add to both a random number generated by two uniform distributions. ${ }^{26}$ Figure 2 (Definition of Grid) locates the random origins of the one hundred grids generated by the random coordinates.

Figure 3 (Random Initial Coordinates) shows the results of running the basic regression (Column 1 of Table 2) one hundred times using cells generated by grids with the initial random coordinates shown in Figure 2. Figure 3 shows that all the parameter estimates are statistically significant no matter the initial coordinates of the grid. In addition, the estimates move mostly in a close range between 0.7 and 0.9 .

26. See Data Appendix for a detailed explanation of the process of generating these grids. 


\section{IV.D. Some additional analyses of robustness}

We have run many other robustness analyses. In Table 7 we use alternative measures of ethnic diversity. In Column 1 we find that the results are robust to the use of ethnic fractionalization calculated as the percentage of population living in the ethnic homeland. The empirical findings are basically unaffected if we use other sources of ethnic diversity such as Ethnologue, or if we use Murdock's data in the analysis of the African case (Columns 2 and 3$)^{27}$. In Column 4 we show that results are robust to dropping the outliers. ${ }^{28}$

In Table 8 we investigate if the results are heterogenous depending on country characteristics. In Columns 1 and 2 we show that the effect of ethnic heterogeneity, at this level of local analysis, does not depend robustly on the quality of country's political institutions ${ }^{29}$. In Column 3 we show that there is no heterogeneous effect of ethnic diversity as a function of the level of development of the countries. Column 4 does not support the heterogeneity of the effect of ethnic diversity as a function of the ruggedness of the country. Finally, Column 5 shows that there are no heterogenous effects of ethnic diversity depending on the general diversity of the country as a whole. ${ }^{30}$

27. The results are also unaffected if we measure diversity as the number of ethnic groups.

28 . The results are also robust to the use of the level of night light per capita instead of the growth rate. However, the use of the growth rate has some advantages since we can control for some omitted variables by using the initial level of development.

29. One could argue that it is decentralization, and not the quality of national institutions, that matters for the effect of ethnic diversity. However, we have run the regressions using the interaction of ethnicity and the degree of decentralization of the countries without finding any statistically significant result.

30. Previous versions of the paper included the estimation using two alternative instrumental variables. The results confirmed the findings discussed above. However, due to the difficulty of justifying the appropriateness of these instruments, we prefer to avoid any detailed discussion of the results. 


\section{Changing the Grid Resolution}

The literature on the influence of diversity on development has analyzed different sized jurisdictions, from cities to countries. However, the observations have always been subject to political or administrative borders that could compromise the exogeneity of the country/region/county/city degree of diversity. In this section we show the effect of a progressive change in grid size on the relationship between ethnic diversity and growth. ${ }^{31}$ Figure 4 shows that for a high degree of resolution (cells of 0.5 by 0.5 degrees up to 1.5 by 1.5 degrees) there is a positive and statistically significant effect of ethnic diversity on growth, as we have seen in previous sections. However, increasing the size of the observations above 1.5 by 1.5 degrees reduces the effect and turns it statistically insignificant.

Table 9 shows that, at minimum resolution (country level), the effect of ethnic diversity on growth is not statistically significant. This result is consistent with previous research using cross-country data. In Column 1 we use our measure of ethnic fractionalization constructed using GREG, the measures of economic growth constructed using night light data, and all the controls (corresponding to Column 5 in Table 2). In Column 2 we use the measures of ethnic fractionalization constructed using the population that lives in ethnic homelands. In column 3 we use data from the PWT 7.1 instead of night light. And finally, in column 4 we use the usual sources for cross-country regressions of growth on ethnic fractionalization: data from the Atlas Narodov Mira to construct the fractionalization measure, and data from PWT 7.1 to construct the growth measure. In all cases ethnic diversity has no effect on economic growth. $^{32}$

31. We use the baseline specification of Column 1 in Table 2.

32. This provides additional evidence of the usefulness of night light for the type of exercises that we are performing. 


\title{
VI. A Potential Mechanism: The Case of
}

\begin{abstract}
AFRICA
Why is diversity good for units of small size and irrelevant at larger sizes? In the second section we discussed several mechanisms that could explain the reduction of the influence of diversity on development as the size of the relevant unit of observation increases. We argued that the mechanisms that explain the basic findings of this paper may depend on the characteristics of the group of countries being analyzed. In this section we suggest a potential mechanism to explain the positive relationship between ethnic fractionalization and growth in Africa based on the possibility that ethnic diversity can increase trade when observed at high resolution. Assuming that members of different ethnic groups have less trust in one another than in members of the same group, trade across ethnic groups implies the need to monitor, and be able to retaliate in cases of non-fulfillment of contract conditions. Trade across ethnic groups therefore requires proximity. As it is not possible to find data on trade across ethnic groups and thus provide some evidence of the likelihood of this mechanism, we rely on an indirect argument. As shown by Michalopoulous (2012), ethnic groups tend to specialize. Using our data we similarly find evidence of ethnic specialization. Moreover, high variability in the proportion of crops in an area is associated with high growth. Therefore, one potential mechanism to explain the positive effect of ethnic diversity on development is the fact that the specialization in production of different ethnic groups provides larger opportunities for welfare improvement through trading with other ethnic groups. This implies that if this effect is larger than the transaction cost associated with lower levels of trust or communication issues, we should find local markets at the ethnic borders.

A theoretical explanation for these effects can be derived from a variation of
\end{abstract}


the trade game with social norms presented in Rohner, Thoening, and Zilibotti (2013). The salience of social norms is heterogeneous across individuals and groups, and determines the psychological benefit derived from agents by playing cooperatively. This benefit is assumed to be group specific but exogenous. However, it seems reasonable to assume that this psychological benefit depends on the proximity of ethnic groups: it is more likely that nearby groups share some social norms than those far away from one another. It is important to get along with your neighbors but less important to follow the social norms of individuals with whom little interaction is foreseen . Therefore, the boundaries between ethnic groups should attract trade.

To investigate this mechanism we have chosen the case of Africa, as this is the region of the world where most of the research on the issue of ethnic diversity is concentrated. Africa is a particularly interesting case for analysis when dealing with the relationship between ethnic diversity and growth as the latter is the most ethnically diverse region of the world. Before analyzing the location of markets in Africa, we first show that the general results on the relationship between ethnicity and growth also hold for Africa. In Table 10 we run the main regression for the African continent and the relationship between diversity and growth remains positive at the same level of resolution as for the original results for the whole world. Columns 1 to 3 show that the basic result is unaffected by the inclusion of an increasing set of observables. Within Africa, areas around the equator seem to be the poorest and most diverse. For this reason we check the role of the equator in the basic relationship. In Column 4 we include a dummy that has value 1 if the cell is on or within an area of $+10 /-10$ degrees from the equatorial line, and zero otherwise. Column 5 reports the results of the regression using a dummy that takes value 1 if the cell is within $+5 /-5$ degrees from the equator. The results are robust to the inclusion of these controls for 
the equator. Therefore, we also observe in Africa that more ethnically diverse areas are also those that grow faster.

\section{VI.A. Interethnic trade and markets in Africa}

There are a number of indications that interethnic trade is at the origin of many African local markets. Most of this interethnic trade took place at the boundaries of ethnic homelands. The evidence draws mostly on work by geographers, anthropologists, and historians who have studied the origin of traditional markets in Africa before the arrival of Europeans. For example, Hodder (1965) provides a voluminous body of evidence to support the view that external trading contacts were critical for the genesis of markets in Africa. Hodder (1965) remarks that "the analysis of Yorubaland, for example, indicated that traditional markets were often located at junction zones, areas in which products of each area could be easily exchanged. Also markets were found at the junction of different people: Ketu market, for instance, was regarded as an important link between Yoruba and Dahomey peoples; Iperu market was a contact point between Egba and Ijebu groups of the Yoruba; mamu market was a traditionally frontier market between Ijebu and Ibadan Yoruba" (p. 99). Hodder (1965) adds that "traditional markets are also found among the more southerly groups of the largest tribe, the Kikuyu. These Southern Kikuyu are known to have traded not only among their own tribal groups and sub-groups but also with neighboring tribes, notably the Masai and Kamba, who in turn traded with Arab and Swahili caravans and acted as middlemen between the coastal and interior traders. In Kenya, too, the Teita have traditional markets and have long been noted for their caravan trading to and from the coast. The Buganda, Busoga and Swahili-speaking coastal peoples also have traditional markets; and all are known to have had important trading contacts with peoples and routes 
outside their own territorial boundaries. Finally in East Africa, the coastal Digo tribe of the north-eastern Bantu are unlike their immediate Bantu neighbors in having traditional market institutions; and these Digo, significantly, have long enjoyed 'an influential position as middlemen in the ivory trade and traded with the Swahili, Arab and Indian merchants..... Even among those peoples where traditional markets do not exist, a few isolated traditional markets may often be found around the periphery of the tribal lands where inter-tribal trade, for instance, seems for long to have existed along the Ubangi River in boundary between the Ngbandi and Banda peoples. Similar peripheral found along the borders of the Ruandi and the Urundi groups" (p. 101).

There is plenty of additional evidence of the interethnic origin of markets in Africa. Meillassoux (1965) analyzes the case of the Guro land in Ivory Coast, where "markets among the Guro of central Ivory Coast tend to be localized at the contact area between complementary zones," supporting the conclusion that "markets are primarily induced by external exchange of complementary products with an alien population. When such a situation occurs, the markets tend to be localized at the contact area between complementary zones. Hence, they can help to indicate the limits of substantive economic areas" (p. 297298). Vansina (1965) draws an almost identical conclusion with regard to the traditional markets of the Kuba peoples of present-day Zaire.

Roberts (1970) highlights that precolonial commerce in the interior of Tanzania was an activity involving different peoples including Nyamwezi, Sumbwa, Gogo, Taturu, Sukuma, Vinza and Sagara who exchanged complementary products which circulated within and between regional trade networks.

Yet another compelling example is that of the Abyssinian market town covered by Messing (1965): "There is relatively little exchange of any kind outside the extended-family and rural hamlets except for that taking place on daily and 
weekly markets. On certain seasonal occasions, over 1,000 persons may gather in and about the weekly market at Gondar. Money is used as both medium of exchange and standard of value. The market is closely related to the division of labor which is caste-like in its ethnic specialization of occupations, such as smiting, pottery-making and tanning" (p. 387).

\section{VI.B. Empirical results}

Assuming that trade at the local level usually takes place in markets, we look for data on the latter. To this end, Porteous (2015) has gathered information on the location of 223 markets in Africa. The distribution of markets by size of the population sees $60 \%$ of markets located in cities of more than 100,000 inhabitants and $40 \%$ in small rural villages.

We overlap Porteous' map with our own map of the spatial distribution of ethnic groups in Africa in Figure 5. It is easy to see that many of the markets are very close to ethnic borders. In fact, the average distance to the closest ethnic border among all the markets is just $27 \mathrm{~km}$, which seems to indicate that trading markets are located close to ethnic borders. Diagram 2 zooms in one of Figure 5's typical markets (the Gambela market), to show how ethnic groups and ethnic borders are distributed around it. In order to show how far the actual distribution of markets is with respect to a random geographic distribution, we run a simulation with 500 random samples of 223 locations in Africa (equal to the number of markets in Porteous, 2015) ${ }^{33}$. We consider continental subSaharan Africa, which is the area similarly covered by Porteous (2015), and use the Haversine formula to estimate the distance of each simulated market to the closest ethnic border. Finally, we take the average distance to the closest ethnic border for each of the 500 simulations. The results reported in Figure 33. We thank Stelios Michalopoulos for this suggestion. 
6 show that the average distance of $27 \mathrm{~km}$ is at the $1 \%$ of the distribution. This indicates that markets are much closer to ethnic borders than randomly generated locations.

Figure 7 provides additional evidence for the concentration of trading along the ethnic borders. It shows the average ethnic diversity index for the actual location of the markets and the 500 simulations of markets' distribution in SubSaharan Africa. For the placebo analysis we randomly generate the location of 223 "virtual" markets, or the actual number of markets identified by Porteous (2015). In each simulation we use a buffer of $50 \mathrm{~km}$ to calculate their index of ethnic diversity. Figure 7 shows that the ethnic diversity of the actual markets is in the tail of the distribution of heteregeneity indices of the "virtual" markets. Figure 8 runs a similar exercise to Figure 7 but relating market location and growth. It shows that the growth rate around the markets is much higher than the growth rate around the "virtual" markets. Table 11 presents the regressions of the presence of a market on the degree of ethnic fractionalization. Column 1 shows that the higher the ethnic fractionalization, the higher the probability of finding a market. In addition, Column 2 shows that the existence of a market leads to a higher growth rate conditional on the initial level of development.

Previous evidence shows that areas that have more ethnic diversity also have more markets. A possible explanation is based on the specialization of ethnic groups. The geographic proximity of ethnic groups may also increase trade if they are highly specialized in the production of specific agricultural products or services. While the level of trust among different ethnic groups may, in general, be smaller than intragroup trust, the fact that they are geographically close to one another can facilitate monitoring and, therefore, counterbalance the potential lack of trust. Jha (2013) shows that medieval Hindus and Muslims could provide complementary services and a mechanism to share gain from 
trade which increased tolerance between these two groups. The development of these practices into formal institutions generated inertia in the degree of ethnic tolerance. ${ }^{34}$ The location of local markets in Africa seems to support this interpretation.

\section{CONCluding Remarks}

The relationship between ethnic heterogeneity and development is complicated. Empirical research working with cross-country data finds a negative, or null, relationship. However, research at the city level usually finds a positive relationship between diversity and wages and/or productivity. In this paper we perform a systematic analysis of the effect of the size of geographical units on the relationship between ethnic diversity and growth. We find that small areas tend to generate a positive relationship while for larger areas there is no relationship. We argue that a possible explanation of the positive relationship between diversity and growth in Africa is the increase in trade at the boundaries between ethnic groups due to ethnic specialization.

Department of Economics and Business, Universitat Pompeu Fabra, ICREA-Academia and IPEG (Institute of Political Economy and Governance)

Department of Economics and Business, Universitat Pompeu Fabra, ICREA And IPEG (Institute of Political Economy and Governance)

34. Jha (2013) also finds that medieval ports, despite being more ethnically diverse, were less prone to conflicts between ethnic groups. 


\section{REFERENCES}

Aker, J., M. Klein, S. O'Connell and M. Yang (2014), "Borders, ethnicity and trade," Journal of Development Economics, 107, 1-16.

Alesina, A., J. Harnoss and H. Rapoport (2016), "Birthplace Diversity and Economic Prosperity," Journal of Economic Growth, 21 (2), 101-138.

Alesina, A., S. Michalopoulos, and E. Papaioannou (2016), "Ethnic Inequality," Journal of Political Economy, 124 (2), 428-488.

Alesina, A., A. Devleeschauwer, W. Easterly, W., S. Kurlat, and R. Wacziarg (2003), "Fractionalization," Journal of Economic Growth, 8, 155-194.

Alesina, A., W. Easterly and J. Matuszeski (2011), "Artificial states," Journal of the European Economic Association, 9 (2), 246-277.

Alesina, A. and E. La Ferrara (2005), "Ethnic diversity and economic performance," Journal of Economic Literature, 43 (3), 762-800.

Alesina, A. and E. Spolaore (1997), "On the Number and Size of Nations." Quarterly Journal of Economics, 112(4), 1027-56.

Alesina, A., E. Spolaore, and R. Wacziarg (2000), "Economic Integration and Political Disintegration," American Economic Review, 90(5), 1276-96.

Ashraf, Q. and O. Galor (2013), "The out of Africa hypothesis, human genetic diversity and comparative development," American Economic Review, 103 (1), 1-46.

Bakens, J., Mulder, P. and Nijkamp, P. (2013), "Economic impacts of cultural diversity in the Netherlands: productivity, utility, and sorting," Journal of Regional Science, 53, 8-36.

Chen, X., and W. D. Nordhaus (2011), "Using Luminosity Data as a Proxy for Economic Statistics," Proceedings of the National Academy of Sciences, 108(21), 8589-8594.

Collier, P. (2001), "Ethnic diversity: An Economic Analysis of its Implications," Economic Policy, 32, 129-166.

Desmet, K., Ortuño-Ortin I. and R. Wacziarg (2012), "The Political Economy of Linguistic Cleavages," Journal of Development Economics, 97, 322-338.

Dincer O.C., and F. Wang (2011), "Ethnic diversity and economic growth in China," Journal of Economic Policy Reform, 14 (1), 1-10.

Easterly, W. (2001), "Can Institutions Resolve Ethnic Conflict," Economic Development and Cultural Change, 49 (4), 687-706.

Easterly, W., and Levine (1997), "Africa's growth tragedy: Policies and Ethnic divisions, " Quarterly Journal of Economics, 112 (4), 1203-1250.

Glaeser, E. L. (2005), "The political economy of hatred," Quarterly Journal of Economics, 45-86.

Glaeser, E. L, Scheinkman J. A., and A. Shleifer (1995), "Economic Growth in a Cross-Section of Cities." Journal of Monetary Economics, 36 (1), 117-143.

Gören, E. (2014), "How Ethnic Diversity Affects Economic Growth," World Development, 59, 275-297.

Gotway, C. A. and L. J. Young (2002), "Combining Incompatible Spatial Data," Journal of the American Statistical Association, 458 (97), 632-648. 
Greif, A. (2006), "The birth of impersonal exchange: the Community responsibility system and impartial justice," Journal of Economic Perspectives, 20 (2), 221-236.

Greif, A. (2000), "The fundamental problem of exchange: A research agenda in Historical Institutional Analysis, European Review of Economic History, 4, 251-284.

Greif, A. (1993), "Contract enforceability and economic institutions in Early trade: the Maghribi traders' coalition," American Economic Review, 83 (3), 525-548.

Henderson, J. V., A. Storeygard and D. Weil (2012), "Measuring Economic Growth from Outer Space," American Economic Review, 102, 994-1028.

Hodder, B. W. (1965), "Some comments on the origin of traditional Markets in Africa South of the Sahara," Transactions of the Institute of British Geographers, 36, 97-105.

Jha, S. (2013), "Trade, Institutions and Ethnic Tolerance: Evidence from South Asia," American Political Science Review, 107 (4), 806-832.

Jean, N., Burke, M., Xie M., Davis, M., Lobell, D. B. and S. Ermon (2016), "Combining satellite imagery and machine learning to predict poverty," Science, $353(790)$. .

Lee, N. (2014), "Migrants and ethnic diversity, cities and innovation: Firm effect or city effects?," Journal of Economic Geography, 1-28.

Lee, N. (2011), "Ethnic diversity and employment growth in English cities," Urban Studies, 48, 407-425.

Meillassoux, C. (1965), "Social and economic factors affecting markets in Guro land," in P. Bohannan and G. Dalton (Eds.), Markets in Africa, Evanston: Northwestern University Press.

Messing, A. D. (1965), "The Abyssinian market town," in P. Bohannan and G. Dalton (Eds.), Markets in Africa, Evanston: Northwestern University Press.

Michalopoulos, S. (2012), "The Origins of Ethnolinguistic Diversity," American Economic Review, 102(4), 1508-1539.

Michalopoulos, S., and E. Papaioannou (2016), "The Long Run Effects of the Scramble for Africa," American Economic Review, 106 (7), 1802-1848

Michalopoulos, S., and E. Papaioannou (2014), "National Institutions and Subnational Development in Africa," Quarterly Journal of Economics, 129(1), $151-213$.

Michalopoulos, S., and E. Papaioannou (2013), "Pre-colonial Ethnic Institutions and Contemporary African Development," Econometrica, 81(1), 113-152.

Montalvo, J. G. and M Reynal-Querol (2017), "Earthquakes and Inequality", mimeo.

Montalvo, J. G. and M Reynal-Querol (2005), "Ethnic Diversity and Economic Development," Journal of Development Economics, 76, 293-323.

Nathan, M. (2011), "The long term impact of migration in British cities: diversity, wages, employment and prices," SERC Discussion Paper, 67.

Ottaviano G. P., and G. Peri (2005), "Cities and Cultures, "Journal of Urban Economics, 58(2), 304-307. 
Ottaviano, G. P., and G. Peri (2006), "The economic value of cultural diversity: evidence from US cities," Journal of Economic Geography, 6, 9-44.

Pinkovskiy, M. and X. Sala-i-Martin (2016), "Lights, camera... income! Illuminating the national account-household surveys debate," Quarterly Journal of Economics, 579-631.

Porteous, O. (2015), "High Trade Costs and Their Consequences: An Estimated Dynamic Model of African Agricultural Storage and Trade," mimeo.

Roberts, A. (1970), "Nyamwezi Trade," in R. Gray adn D. Birmingham (Eds.), Pre-colonial African Trade, London.

Rohner, D., Thoening, M. and F. Zilibotti (2013), "War Signals: a Theory of Trade, Trust and Conflict," Review of Economic Studies, 80 (3), 1114-1147.

Sparber C. (2010), "Racial Diversity and Macroeconomic Productivity across US States and Cities,", Regional Studies, 44(1), 71-85.

Suedekum, J., Wolf, K. and U. Blien (2014), "Cultural diversity and local labor markets," Regional Studies, 40, 173-191.

Vansina, J. (1965), "Trades and markets among the Kuba," in P. Bohannan and G. Dalton (Eds.), Markets in Africa, Evanston: Northwestern University Press.

Weidmann, N. B., Rod, J. K. and L. E. Cederman (2010), "Representing Ethnic Groups in Space: A New Dataset," Journal of Peace Research, 47(4): 491-99. 
Appendix I 


\section{Grid Simulation}

In order to determinate whether our results are driven by the geographical definition of our cell, we randomly generate 100 different cells to replicate our results. Based on our baseline starting coordinates (i.e. $X_{0}($ longitude $)=$ $-180, Y_{0}$ (latitude $\left.)=-89\right)$, we generate 100 new starting coordinate in the following manner: $\left(X_{0}+\epsilon_{i}, Y_{0}+\xi_{i}\right.$, where, $\epsilon_{i}, \xi_{i} \sim \operatorname{Uniform}(0,1), \forall(i=$ $1, \ldots, 100)$ ). As a result, we could have 100 different cells for all across the world (see Figure 1).

Figure 1: Random initial coordinate

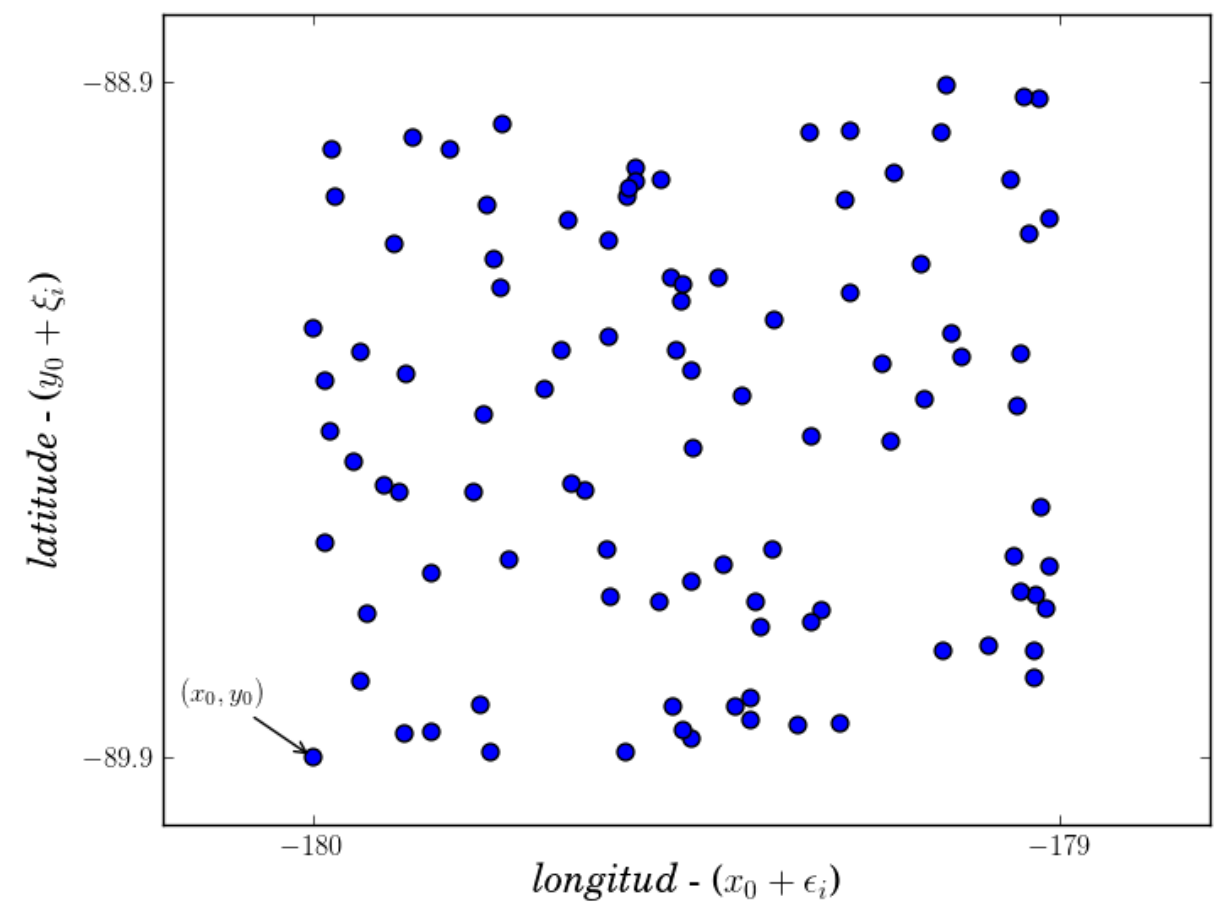

Once we simulate the new random grids and intersect them with the political borders, we rebuild our data set for each new cell definition. Graph 2 shows the point estimate for Ethnic Fractionalization and its Confidence Interval for 100 simulated grids. We estimate the specification of Table 2 column 1. In general, point estimates are always significant and have the 
same magnitude. Therefore, we can conclude that our results are robust to the initial coordinates of the grid that produced the hundred-cells.

Figure 2: Point Estimates for the different random initial coordinate

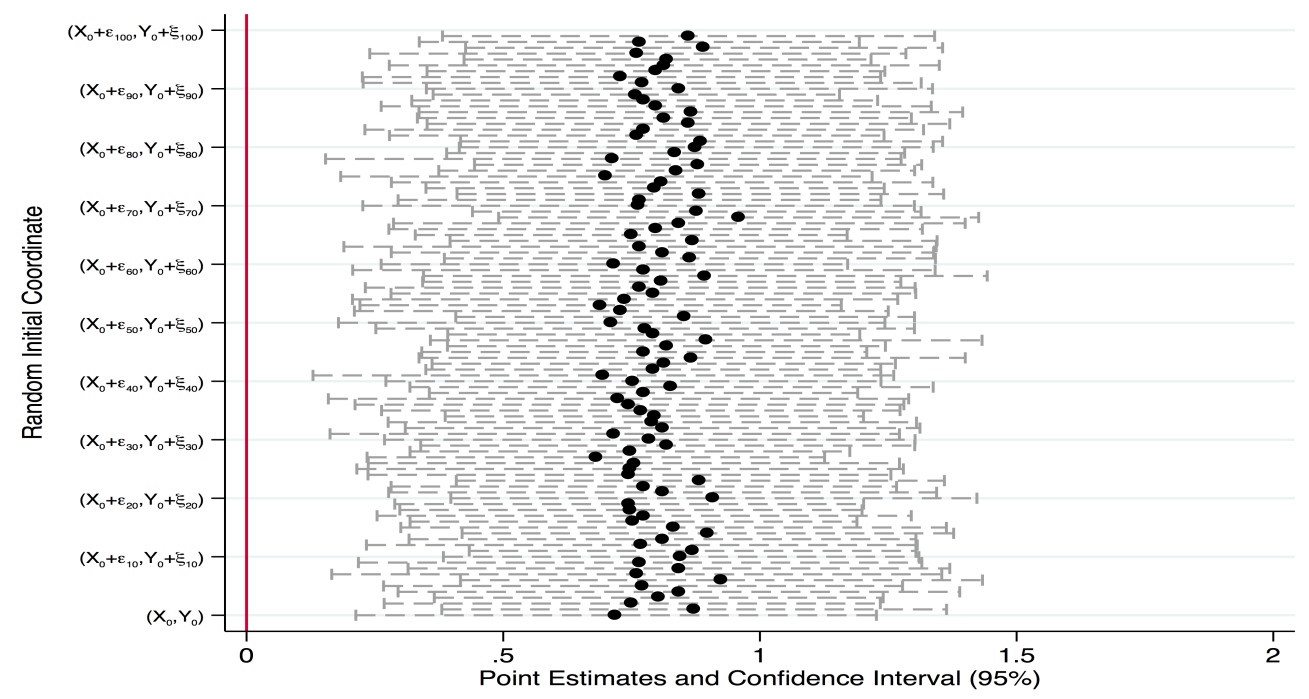

Notes - $\mathrm{T}$ Our baseline starting points are: $X_{0}$ (longitude $)=-180$ and $Y_{0}$ (latitude) $=-89 . \quad \epsilon_{i}, \alpha_{i} \sim$ $\operatorname{Uniform}(0,1), \forall(i=1, \ldots, 100)$

\section{Data Description}

\section{$2.1 \quad$ Baseline OBS}

Our baseline units of analysis (OBS) are the result of intersecting 1 degree per 1 degree cell grids and the national political borders $\square$. Political borders are provided by The Global Administrative Unit Layers (2010) -GAULproject from UN Food and Agriculture Organization (FAO). The GAUL compiles a very high quality information on the different administrative units

\footnotetext{
${ }^{1}$ Based on the extend of the political borders layer, we set the starting point for the grid cells at longitude $=-180$ and latitude $=-89$.
} 
for all the countries in the world 2. We use EPSG:4326 - WGS 84 as our coordinate system. To estimate distance and areas in meters, we re-project to EPSG:3857 - WGS 84.

\subsection{Economy Growth, 1992-2010}

To build a proxy income per-capita we estimate the nighlight per-capita in 1992 and 2010 for each cell. Firstly, we use the cloud-free night-light data provided by the NOAA'S National Geophysical Data Center, specifically the Earth Observation Group (EOG) 3 . It provides information at 30 arc second grids 4 , on the average quantity of light observed at each grid across cloud-free nights for every year 5 . We use information from 1992 and 2010 collected by satellites F10 and F18 respectively. Although information are collected using different satellites, it is comparable.

Secondly, to estimate population we use the Gridded Population of the World (GPWFE) 6. Based on national census and satellite images, it provides information on human population at 2.5 arc-minutes resolution for 1990, 1995, and 2000, 2005 (projected), 2010 (projected) and 2015 (projected).

Once we estimate the total nighlight and population per cell, we estimate the proxy of the economy growth as follows:

$$
\text { Growth }_{1992-2010}=\ln \left(\frac{0.1+\text { nighlight }_{2010}}{0.1+\text { population }_{2005}}\right)-\ln \left(\frac{0.1+\text { nighlight }_{1992}}{0.1+\text { population }_{1990}}\right)
$$

\footnotetext{
${ }^{2}$ Data is available at: http://www.fao.org/geonetwork/srv/en/metadata.show?id= 12691\&currTab=simple

${ }^{3}$ For further information and data at http://www.ngdc.noaa.gov/eog/

${ }^{4}$ spanning from -180 to 180 degrees longitude and -65 to 75 degrees latitude

${ }^{5}$ Values range from 1 to 63 .

${ }^{6}$ Center for International Earth Science Information Network (CIESIN), Columbia University; United Nations Food and Agriculture Programme (FAO); and Centro Internacional de Agricultura Tropical (CIAT). 2005. Gridded Population of the World: Future Estimates (GPWFE). Palisades, NY: Socioeconomic Data and Applications Center (SEDAC), Columbia University. Available at http://sedac.ciesin.columbia.edu/gpw (downloaded on July 2015).
} 


\subsection{Ethnic Fractionalization}

As measure of ethnic diversity at cell level we use the Herfindhal Index - HIof the ethnic groups territories. We use Geo-referencing of Ethnic Groups -GREG- data set7, which provides the geospatial location of ethnic groups as polygons. By intersecting our cells and group territories, we are able to estimate the share of area within each cell by groups. Then, we estimate the $\mathrm{HI}$ as follows:

$$
F R A C=1-\sum_{i=1}^{N} \pi_{i}^{2}=\sum_{i=1}^{N} \pi(1-\pi)
$$

where $\pi$ is the proportion of area/population who belong to ethnic group $i$ in a given $(\forall i=1, \ldots, N)$.

\subsection{Average precipitation and temperature, 1961-1990}

We use 10-minute latitude/longitude data set of mean monthly surface climate over global land areas, excluding Antarctica (CRU TS3.10 Dataset) 8. It provides a detailed information on the monthly average precipitation (mm/month) and the temperature (Degrees Celsius) from 1961 to 19909 , We first take the overall average of the monthly information at 10-minute latitude/longitude, and then average at our cell level.

\subsection{Share Mining}

We use the Seamless Digital Chart of the World $(\mathrm{SDCW})^{10}$ which provides a unique information on areas where natural resources are being extracted from the earth 11 . The SDCW is based on the best currently-available global

\footnotetext{
${ }^{7}$ Further information and data available at http://www.icr.ethz.ch/data/other/ greg

${ }^{8}$ Harris, I; Jones,P.D.; Osborn, T.J. and Lister, D.H.. "Updated high-resolution grids of monthly climatic observations the CRU TS3.10 Dataset". International Journal of Climatology: Volume 34, Issue 3, pages 623642, 15 March 2014

${ }^{9}$ Data and further methodological information are available through the School of Geography Oxford (http://www.geog.ox.ac.uk), the International Water Management Institute "World Water and Climate Atlas" (http://www.iwmi.org) and the Climatic Research Unit (http://www.cru.uea.ac.uk).

10 www . worldgeodatasets . com/basemaps/

${ }^{11}$ It includes mines/quarries, oil/gas fields, and salt evaporators.
} 
vector base map, Digital Chart of the World (Vector Smart Map 0, Edition 5 from National Geospatial Agency-Intelligence Agency). We are therefore able to determinate the area within each cell that is being used for different type of mining. Then, the share of mining for a given cell $i$ is:

$$
\text { ShareMining }_{i}=\frac{\text { Area Natural Resources Extraction }(k m \mathscr{2})_{i}}{\text { Total Area }(k m 2)_{i}}
$$

\section{$2.6 \quad$ Fertile Soil}

We use the information of fertile soil used by Nun and Puga (2012), which determines whether a each cell on a 5-minute grid covering almost the entire land area of the Earth is subject to various constraints for growing rain-fed crops ${ }^{12}$. Thereby, we estimate the overall mean of the fertile cell at our cells level.

\subsection{Urban Centers, Rivers and Lakes}

In order to capture the information for Urban Centers, Rivers and Lakes we use the SDCW DataSet. It provides the exact location of urban centers (either as points or polygons), rivers (polylines) and lakes(polygons). Based on this information, we built for different variables:

Distance to Capital (km): Euclidean distance from the centroid of our cell to the political capital of the country.

\footnotetext{
${ }^{12}$ This information is originally created by Fischer, van Velthuizen, Shah, and Nachtergaele (2002), based on the FAO/UNESCO Digital Soil Map of the World, the soil association composition table and climatic data compiled by the Climate Research Unit of the University of East Anglia. Based on plates 20 (soil moisture storage capacity constraints), 21 (soil depth constraints), 22 (soil fertility constraints), 23 (soil drainage constraints), 24 (soil texture constraints), and 25 (soil chemical constraints) in Fischer et al. (2002) and the country boundaries described above, we calculate the percentage of the land surface area of each country that has fertile soil (defined as soil that is not subject to severe constraints for growing rain-fed crops in terms of either soil fertility, depth, chemical and drainage properties, or moisture storage capacity). In addition, Nun and Puga (2012) include Cape Verde, French Polynesia, Mauritius and Seychelles that were not covered by the Fischer et al. (2002) data, they we use instead the percentage of their land surface area that is classified by the Food and Agriculture Organization (2008) as arable land or permanent crop land.
} 
Distance to River (km): Euclidean distance from the centroid of our cell to the nearest river.

Distance to Lakes (km): Euclidean distance from the centroid of our cell to the nearest Lake.

National Capital (yes=1): It indicates whether the political national capital is located within a giving cell.

Provincial Capital (yes=1): It indicates whether a provincial capital is located within a giving cell.

\subsection{Terrain Ruggedness Index, 100m}

We use the Terrain Ruggedness Index used by Nunn and Puga (2012) ${ }^{13}$, Each cells on a 30 arc-seconds grid across the surface of the Earth provides the Terrain Ruggedness Index, in millimeter ${ }^{14}$. Then, we estimate the weighted average, using as weights the area of each cell ${ }^{15}$, for each of our obs. Finally, as suggested by Nun and Puga (2012), we obtain divide values by 100,000 to obtain the Terrain Ruggedness Index in hundreds of meters.

\footnotetext{
${ }^{13}$ Nun, N and Puga, D (2012). Ruggedness: The blessing of bad geography in Afric. Review of Economics and Statistics 94(1), February 2012: 20-36

${ }^{14}$ Rawdata is available at http://diegopuga.org/data/rugged/tri.zip

${ }^{15}$ Getting the weighted average is important to take into account that the sea-level surface that corresponds to a 30 by 30 arcsecond cell varies in proportion to the cosine of its latitude (Nun and Puga, 2012).
} 


\section{TABLE I}

Ethnic Diversity and Growth

\begin{tabular}{|c|c|c|c|c|c|c|}
\hline & $\begin{array}{c}\text { All Sample } \\
\text { (1) }\end{array}$ & All Sample & All Sample & $\begin{array}{c}\text { Only } \\
\text { Populated } \\
\text { Areas } \\
(4)\end{array}$ & $\begin{array}{c}\text { Only } \\
\text { Populated } \\
\text { Areas } \\
(5)\end{array}$ & $\begin{array}{c}\text { Only } \\
\text { Populated } \\
\text { Areas } \\
(6)\end{array}$ \\
\hline Log night light 1992 & $\begin{array}{c}-0.252^{* * *} \\
{[0.005]}\end{array}$ & $\begin{array}{c}-0.350^{* * *} \\
{[0.007]}\end{array}$ & $\begin{array}{c}-0.350^{* * *} \\
{[0.022]}\end{array}$ & $\begin{array}{c}-0.264^{* * *} \\
{[0.005]}\end{array}$ & $\begin{array}{c}-0.370^{* * *} \\
{[0.007]}\end{array}$ & $\begin{array}{c}-0.370^{* * *} \\
{[0.022]} \\
(0.014)\end{array}$ \\
\hline Ethnic Fractionalization & $\begin{array}{c}0.501^{* * *} \\
{[0.094]}\end{array}$ & $\begin{array}{c}0.690^{* * *} \\
{[0.096]}\end{array}$ & $\begin{array}{c}0.690^{* * *} \\
{[0.240]}\end{array}$ & $\begin{array}{c}0.425^{* * *} \\
{[0.098]}\end{array}$ & $\begin{array}{c}0.617^{* * *} \\
{[0.100]}\end{array}$ & $\begin{array}{c}0.617^{* *} \\
{[0.287]} \\
(0.154)\end{array}$ \\
\hline Country FE & No & Yes & Yes & No & Yes & Yes \\
\hline Observations & 25693 & 25693 & 25693 & 21514 & 21514 & 21514 \\
\hline R-squared & 0.171 & 0.287 & 0.287 & 0.159 & 0.294 & 0.294 \\
\hline
\end{tabular}

TABLE II

Ethnic Diversity AND Growth: ADDING OBSERVABLES

\begin{tabular}{|c|c|c|c|c|c|}
\hline & (1) & $(2)$ & $(3)$ & (4) & $(5)$ \\
\hline Log night light 1992 & $\begin{array}{c}-0.369^{* * *} \\
{[0.021]}\end{array}$ & $\begin{array}{c}-0.367^{* * *} \\
{[0.021]}\end{array}$ & $\begin{array}{c}-0.369^{* * *} \\
{[0.021]}\end{array}$ & $\begin{array}{c}-0.369^{* * *} \\
{[0.021]}\end{array}$ & $\begin{array}{c}-0.370^{* * *} \\
{[0.021]} \\
(0.013)\end{array}$ \\
\hline Ethnic Fractionalization & $\begin{array}{c}0.720^{* * * *} \\
{[0.258]}\end{array}$ & $\begin{array}{c}0.733^{* * *} \\
{[0.243]}\end{array}$ & $\begin{array}{c}0.725^{* * *} \\
{[0.239]}\end{array}$ & $\begin{array}{c}0.700^{* * *} \\
{[0.247]}\end{array}$ & $\begin{array}{c}0.735^{* * *} \\
{[0.244]} \\
(0.149)\end{array}$ \\
\hline Geographic Variables & Yes & Yes & Yes & Yes & Yes \\
\hline Climate Variables & Yes & Yes & Yes & Yes & Yes \\
\hline Population Density & No & Yes & Yes & Yes & Yes \\
\hline Share Mining and Fertile Soil & No & No & Yes & Yes & Yes \\
\hline Distance to River and Lake & No & No & No & Yes & Yes \\
\hline Border & No & No & No & No & Yes \\
\hline Observations & 21514 & 21514 & 21514 & 21514 & 21514 \\
\hline R-squared & 0.298 & 0.298 & 0.299 & 0.299 & 0.301 \\
\hline
\end{tabular}


TABLE III

EThNiC Diversity By POPULATION DECILE: RANKING

\begin{tabular}{lc}
\hline \# Population (1990) Decile & Ethnic Frac (Mean/std. Deviation) \\
\hline \hline & \\
10 & 0.077 \\
& {$[0.167]$} \\
& 0.133 \\
8 & {$[0.210]$} \\
& 0.140 \\
7 & {$[0.209]$} \\
& 0.129 \\
& {$[0.203]$} \\
5 & 0.126 \\
& {$[0.201]$} \\
4 & 0.108 \\
& {$[0.187]$} \\
3 & 0.115 \\
& {$[0.185]$} \\
2 & 0.106 \\
& {$[0.184]$} \\
& 0.099 \\
& {$[0.175]$} \\
\hline
\end{tabular}

TABle IV

Ethnic Diversity, Population Density and Growth

\begin{tabular}{|c|c|c|c|c|}
\hline \multicolumn{5}{|c|}{ Dependent Variable: Growth } \\
\hline & (1) & $\overline{(2)}$ & 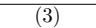 & (4) \\
\hline Ethnic Fractionalization & $\begin{array}{c}0.527^{* * *} \\
{[0.168]}\end{array}$ & $\begin{array}{c}0.728^{* * *} \\
{[0.279]}\end{array}$ & $\begin{array}{l}0.681^{* *} \\
{[0.266]}\end{array}$ & $\begin{array}{l}0.618^{* *} \\
{[0.281]}\end{array}$ \\
\hline ln. Pop Density x Ethnic Frac. & $\begin{array}{c}0.153^{* * *} \\
{[0.053]}\end{array}$ & & & \\
\hline ln. Pop Density & $\begin{array}{l}-0.057 \\
{[0.054]}\end{array}$ & & & \\
\hline Urb. Agglom & & $\begin{array}{l}-0.025 \\
{[0.090]}\end{array}$ & & \\
\hline Pop Dens 9 decile x Ethnic Frac. & & & $\begin{array}{c}0.448 \\
{[0.371]}\end{array}$ & \\
\hline Pop Dens 9 decile & & & $\begin{array}{l}-0.149 \\
{[0.115]}\end{array}$ & \\
\hline Climate Variables & Yes & Yes & Yes & Yes \\
\hline Share Mining and Fertile Soil & Yes & Yes & Yes & Yes \\
\hline Distance to River and Lake & Yes & Yes & Yes & Yes \\
\hline Border & Yes & Yes & Yes & Yes \\
\hline Observations & 21,514 & 21,514 & 21,514 & 21,514 \\
\hline R-squared & 0.302 & 0.300 & 0.300 & 0.300 \\
\hline
\end{tabular}


TABLe V

Ethnic Diversity and Growth: Robustness to Agglomeration

\begin{tabular}{|c|c|c|c|c|c|c|c|c|}
\hline & (1) & $(2)$ & $(3)$ & $\begin{array}{c}\text { Drop } \\
\text { all-urban } \\
\text { center } \\
(4)\end{array}$ & $\begin{array}{c}\text { Drop } 10 \% \\
\text { richest } \\
(5)\end{array}$ & $\begin{array}{c}\text { Drop 20\% } \\
\text { richest } \\
(6)\end{array}$ & $\begin{array}{c}\text { Drop } 10 \% \\
\text { most densely } \\
(7)\end{array}$ & $\begin{array}{c}\text { Drop } 20 \% \\
\text { most densely } \\
\text { (8) }\end{array}$ \\
\hline Log night light 1992 & $\begin{array}{c}-0.370^{* * *} \\
{[0.021]}\end{array}$ & $\begin{array}{c}-0.375^{* * *} \\
{[0.021]}\end{array}$ & $\begin{array}{c}-0.375^{* * *} \\
{[0.021]}\end{array}$ & $\begin{array}{c}-0.367^{* * *} \\
{[0.022]}\end{array}$ & $\begin{array}{c}-0.373^{* * *} \\
{[0.015]}\end{array}$ & $\begin{array}{c}-0.374^{* * *} \\
{[0.016]}\end{array}$ & $\begin{array}{c}-0.375^{* * *} \\
{[0.022]}\end{array}$ & $\begin{array}{c}-0.359^{* * *} \\
{[0.023]}\end{array}$ \\
\hline $\begin{array}{l}\text { Ethnic Fractionaliza- } \\
\text { tion }\end{array}$ & $0.736^{* * *}$ & $0.697^{* * *}$ & $0.699^{* * *}$ & $0.730^{* *}$ & $0.710^{\text {*** }}$ & $0.924^{* * *}$ & $0.697^{* *}$ & $0.561^{*}$ \\
\hline & {$[0.245]$} & {$[0.242]$} & {$[0.246]$} & {$[0.291]$} & {$[0.269]$} & {$[0.183]$} & {$[0.275]$} & {$[0.291]$} \\
\hline Nat. Capital $($ yes $=1)$ & $\begin{array}{l}-0.211 \\
{[0.140]}\end{array}$ & $\begin{array}{c}-0.516^{* * * *} \\
{[0.116]}\end{array}$ & $\begin{array}{c}-0.504^{* * *} \\
{[0.088]}\end{array}$ & & $\begin{array}{c}-0.545^{* * *} \\
{[0.081]}\end{array}$ & $\begin{array}{c}-0.589^{* * * *} \\
{[0.078]}\end{array}$ & $\begin{array}{c}-0.644^{* * *} \\
{[0.215]}\end{array}$ & $\begin{array}{c}-1.409^{* * *} \\
{[0.316]}\end{array}$ \\
\hline Prov. Capital (yes=1) & & $\begin{array}{c}0.512^{* * *} \\
{[0.130]}\end{array}$ & $\begin{array}{c}0.524^{* * *} \\
{[0.127]}\end{array}$ & & $\begin{array}{c}0.545^{* * * *} \\
{[0.122]}\end{array}$ & $\begin{array}{c}0.533^{* * *} \\
{[0.122]}\end{array}$ & $\begin{array}{l}1.044^{* * * *} \\
{[0.179]}\end{array}$ & $\begin{array}{c}1.416^{* * *} \\
{[0.212]}\end{array}$ \\
\hline Urb. Agglom $($ yes $=1)$ & & & $\begin{array}{l}-0.043 \\
{[0.180]}\end{array}$ & & $\begin{array}{l}-0.218 \\
{[0.163]}\end{array}$ & $\begin{array}{c}-0.467^{* * *} \\
{[0.125]}\end{array}$ & & \\
\hline Controls from Table 2 & Yes & Yes & Yes & Yes & Yes & Yes & Yes & Yes \\
\hline Observations & 21,514 & 21,514 & 21,514 & 18,174 & 19,151 & 17,694 & 18,674 & 16,091 \\
\hline R-squared & 0.301 & 0.303 & 0.303 & 0.293 & 0.292 & 0.307 & 0.297 & 0.286 \\
\hline
\end{tabular}

TABLE VI

Ethnic Diversity and Growth: AdDressing Post-1500 Migration

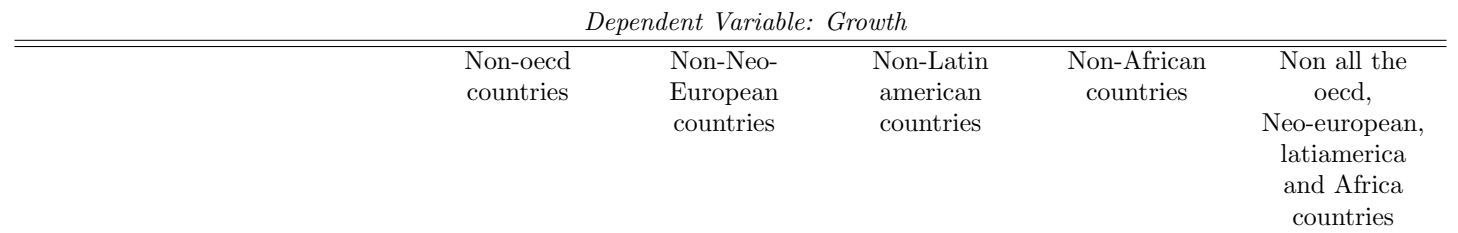

\begin{tabular}{|c|c|c|c|c|c|}
\hline & $(1)$ & $(2)$ & $(3)$ & (4) & $(5)$ \\
\hline \multirow[t]{2}{*}{ Log night light 1992} & $-0.359^{* * *}$ & $-0.383^{* * *}$ & $-0.374^{* * *}$ & $-0.368^{* * *}$ & $-0.349^{* * *}$ \\
\hline & {$[0.015]$} & {$[0.023]$} & {$[0.024]$} & {$[0.025]$} & {$[0.021]$} \\
\hline \multirow[t]{2}{*}{ Ethnic Fractionalization } & $0.761^{* * *}$ & $0.779^{* * *}$ & $0.746^{* *}$ & $0.650^{* *}$ & $0.770^{*}$ \\
\hline & {$[0.262]$} & {$[0.250]$} & {$[0.290]$} & {$[0.297]$} & {$[0.435]$} \\
\hline Geographic Variables & Yes & Yes & Yes & Yes & Yes \\
\hline Climate Variables & Yes & Yes & Yes & Yes & Yes \\
\hline Population Density & Yes & Yes & Yes & Yes & Yes \\
\hline Share Mining and Fertile Soil & Yes & Yes & Yes & Yes & Yes \\
\hline Distance to River and Lake & Yes & Yes & Yes & Yes & Yes \\
\hline Border & Yes & Yes & Yes & Yes & Yes \\
\hline Observations & 15492 & 17950 & 18504 & 17627 & 9343 \\
\hline R-squared & 0.259 & 0.298 & 0.310 & 0.315 & 0.275 \\
\hline
\end{tabular}


TABLE VII

Ethnic Diversity and Growth: Robustness to Alternative data on ETHNICITY



TABle VIII

Other Robust Analysis: Country Variables

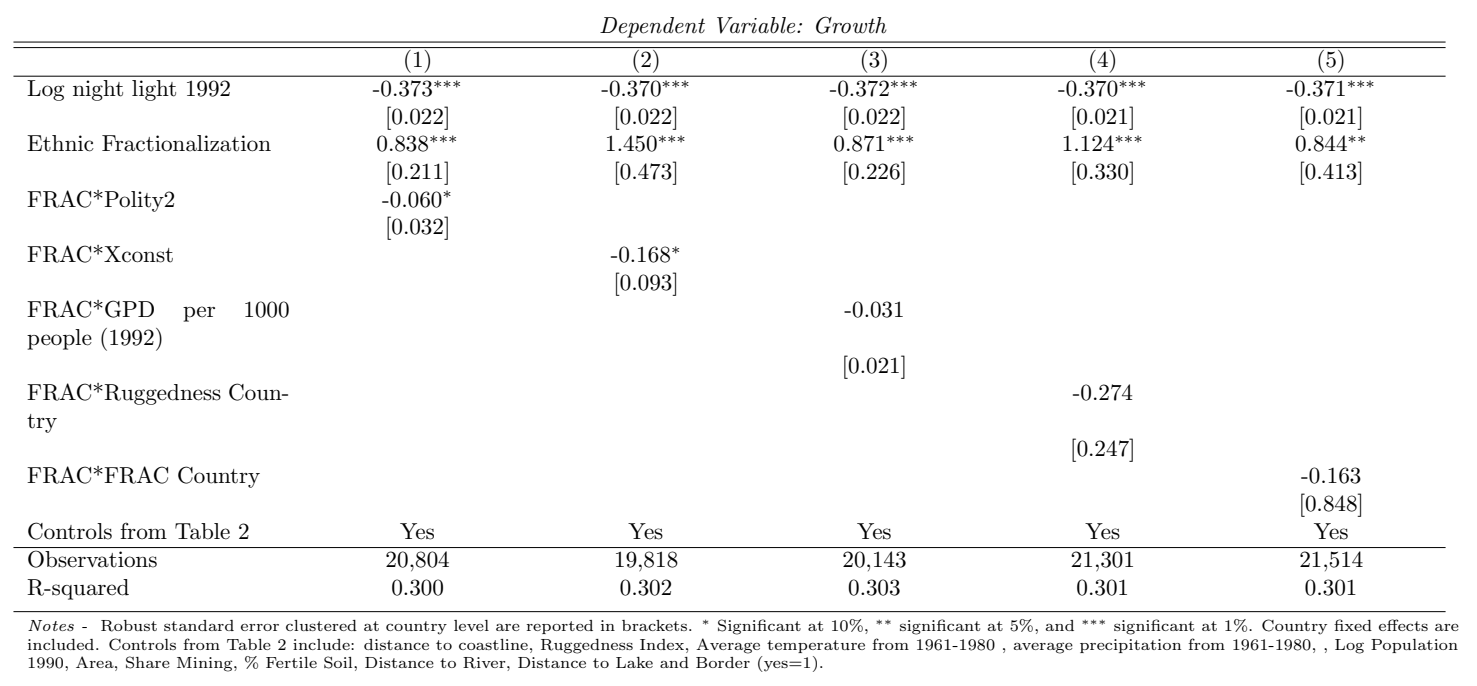


Table IX

Ethnic Diversity and Growth: Country Level Results

\begin{tabular}{|c|c|c|c|c|}
\hline & $\begin{array}{l}\text { Growth } \\
\text { (1) }\end{array}$ & $\begin{array}{c}\text { Growth } \\
(2)\end{array}$ & $\begin{array}{c}\text { Growth PWT7.1 } \\
(3)\end{array}$ & $\begin{array}{c}\text { Growth PWT7.1 } \\
\text { (4) }\end{array}$ \\
\hline Ethnic Fractionalization & $\begin{array}{l}-0.117 \\
{[0.175]}\end{array}$ & & $\begin{array}{c}0.000 \\
{[0.134]}\end{array}$ & \\
\hline Ethnic Fractionalization POP & & $\begin{array}{l}-0.111 \\
{[0.182]}\end{array}$ & & \\
\hline Ethnic Frac. based on Soviet Atlas & & & & $\begin{array}{c}0.128 \\
{[0.113]}\end{array}$ \\
\hline Controls from Table $2^{+}$ & Yes & Yes & Yes & Yes \\
\hline Observations & 233 & 233 & 167 & 139 \\
\hline R-squared & 0.232 & 0.232 & 0.138 & 0.200 \\
\hline
\end{tabular}

Table X

Ethnic Diversity and Growth: the Case of Africa

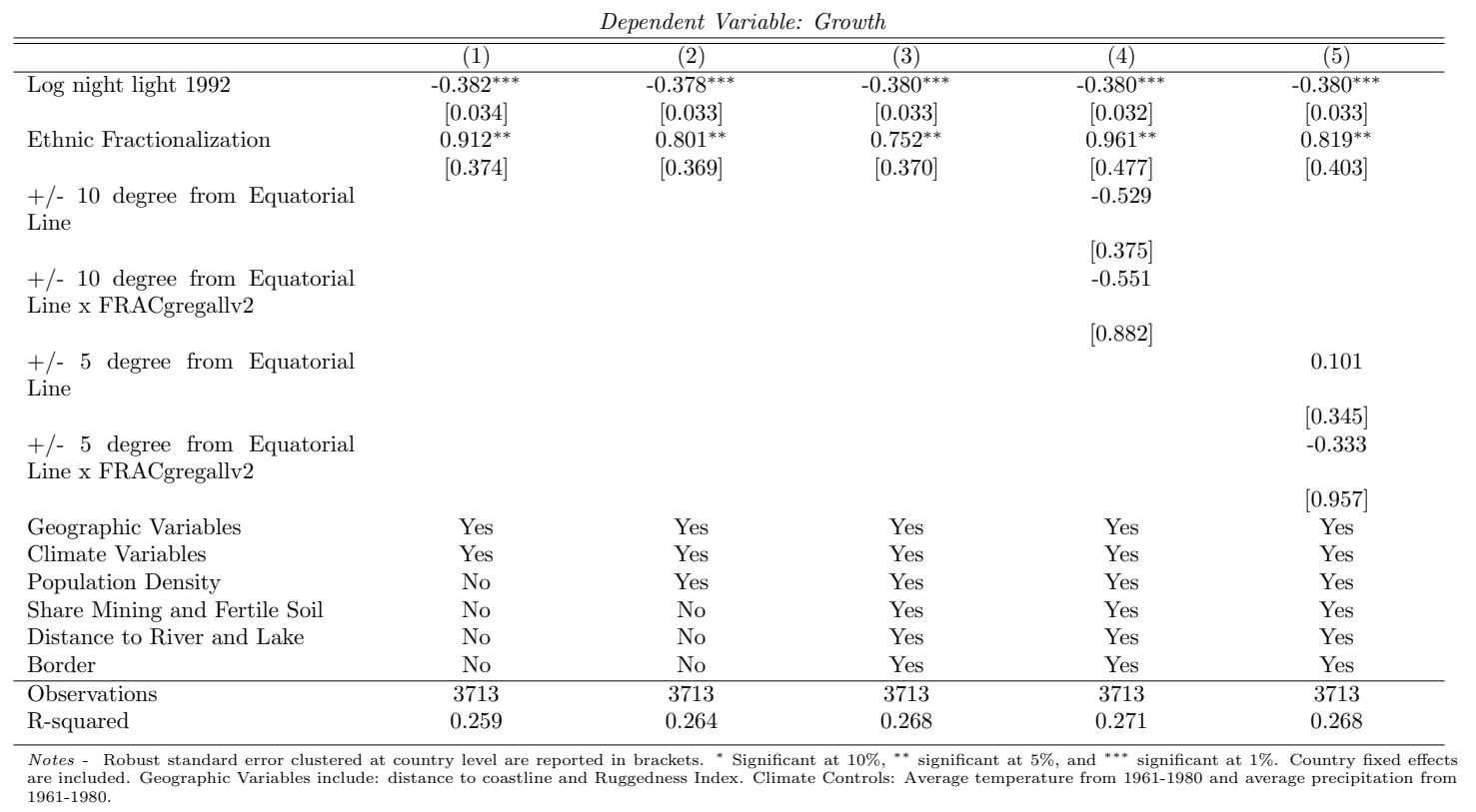


TABLE XI

Ethnic Diversity and Growth: Market Analysis

\begin{tabular}{|c|c|c|}
\hline & Dep. Var: Presence of Market (yes $=1)$ & Dep. Var: Growth \\
\hline & (1) & $(2)$ \\
\hline Log night light 1992 & & $\begin{array}{c}-0.459^{* * * *} \\
{[0.025]}\end{array}$ \\
\hline Ethnic Fractionalization & $\begin{array}{c}0.066^{* * *} \\
{[0.023]}\end{array}$ & \\
\hline Presence of Market $($ yes $=1$ ) & & $\begin{array}{c}1.336^{* * * *} \\
{[0.327]}\end{array}$ \\
\hline Controls from Table 2 & Yes & Yes \\
\hline Observations & 3103 & 3103 \\
\hline R-squared & 0.095 & 0.307 \\
\hline
\end{tabular}


Figure I

Ethnic Borders and Population Density



Notes - This graph shows the population density in 1990 and the ethnicity borders from GREG for Africa. 
FIGURE II

Definition of GRID - Simulation

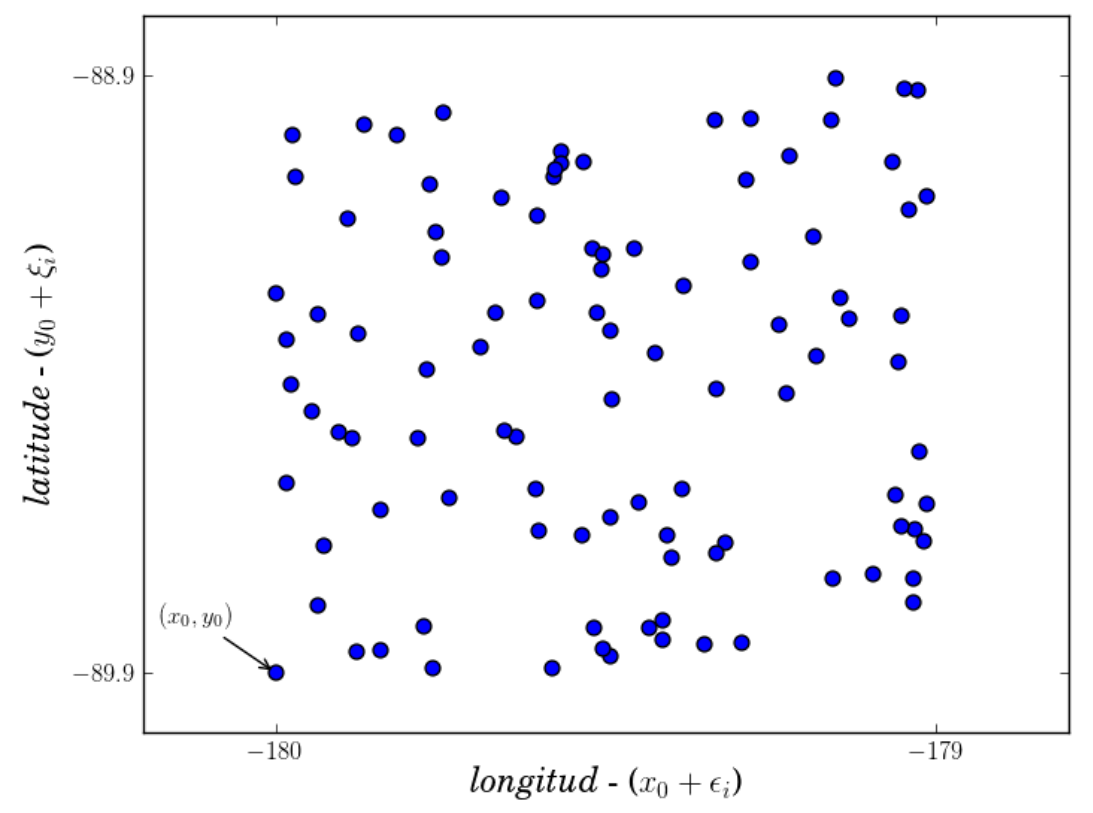

Notes - This graph shows the random initial coordinates generated. Our baseline starting points are: $X_{0}($ longitude $)=-180$ and $Y_{0}($ latitude $)=-89 . \epsilon_{i}, \xi_{i} \sim \operatorname{Uniform}(0,1), \forall(i=1, \ldots, 100)$ 
Figure III

RANDOM Initial CoORdinates

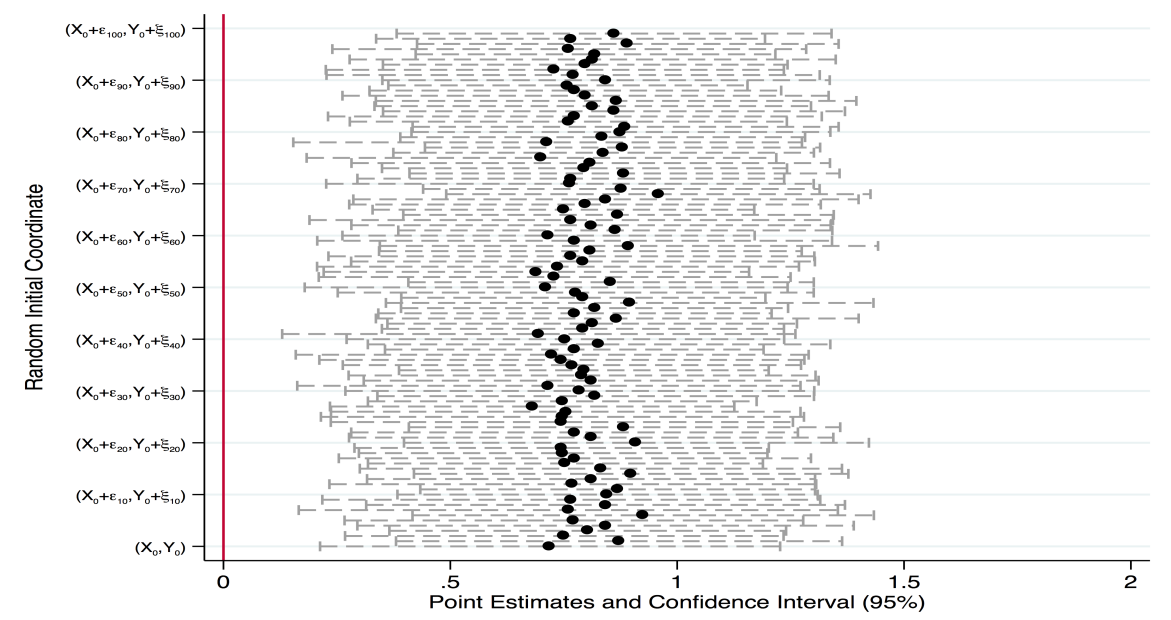

Notes - This graph shows the point estimate for Ethnic Fractionalization and its Confidence Interval for 100 simulated grids. We estimate the specification of Table 2 column 1 . Our baseline starting points are:

Figure IV

Grid Size ANALYsis

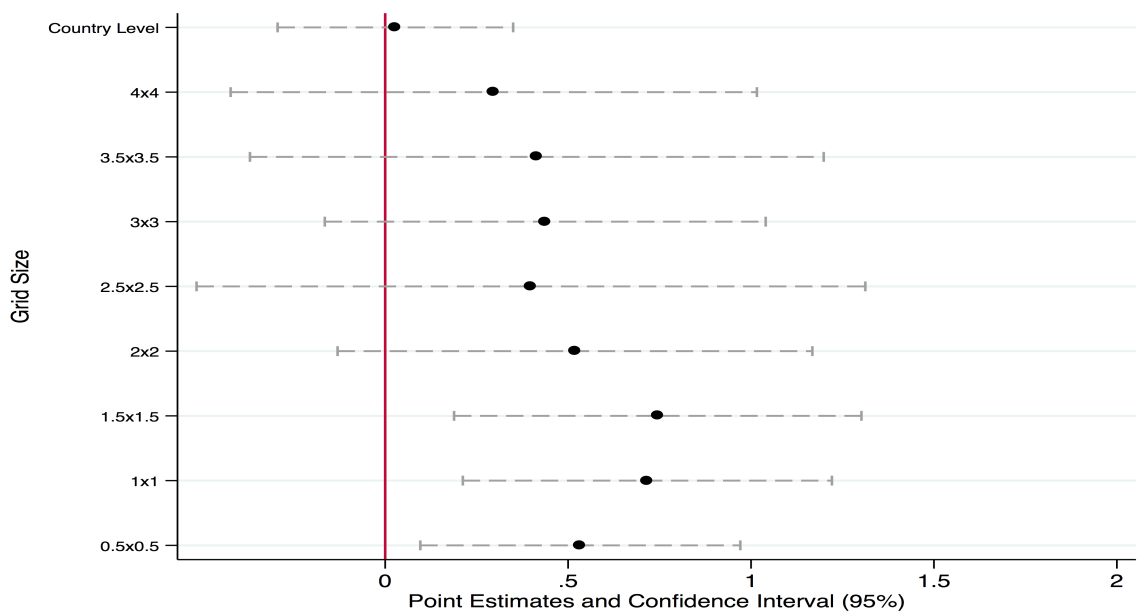

Notes - This graph shows the point estimate for Ethnic Fractionalization and its Confidence Interval for the different Grid Size. We estimate the specification of Table 2 column 1. 
Figure V

\section{Market Location ANd Ethnic Borders}

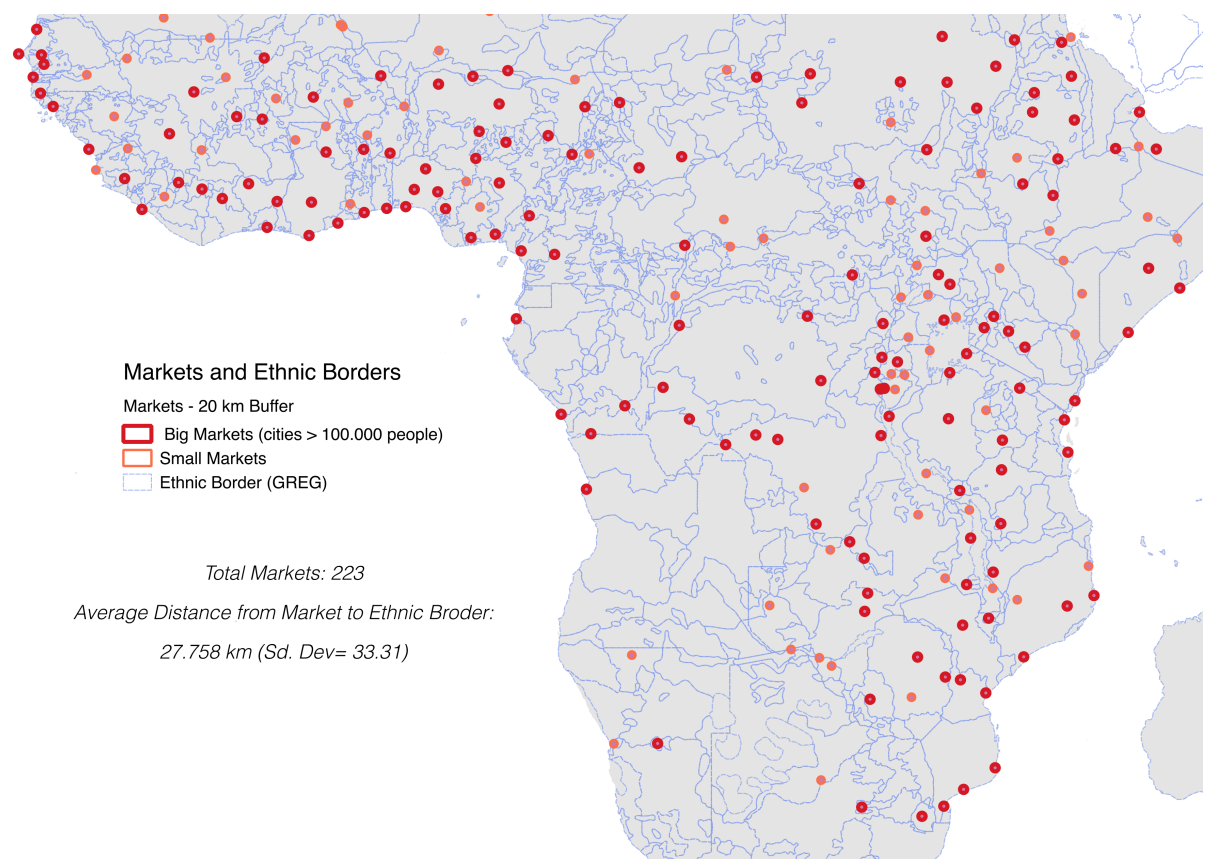

Notes - This graph shows the location of 223 markets in Sub-Saharan Africa identified by Porteous (2015). Markets are defined as: (i) towns and cities which have a population of at least 100,000 people and are at least 200 kilometers apart (if two towns with over 100,000 people are closer than 200 kilometers I include the larger 200 kilometers apart) in countries which still have high population-to-market ratios after my ratios two steps.
nof 
FiguRE VI

Market Location - Simulation



Notes - This graph shows the average distance to the GREG border using the actual location and 500 simulated location market in Sub-Saharan Africa. In each simulation, we randomly generated the location of 224 markets, which are the number of actual number markets located in Africa by Porteous (2015). In all cases, we estimate the Harvesine Distance. On average, whereas the actual location of markets are located at $26 \mathrm{~km}$ to to closest GREG border (located at 1 percentile), the simulated markets are $41 \mathrm{KM}$

FiguRE VII

Market Location and Ethnic Diversity - Simulation
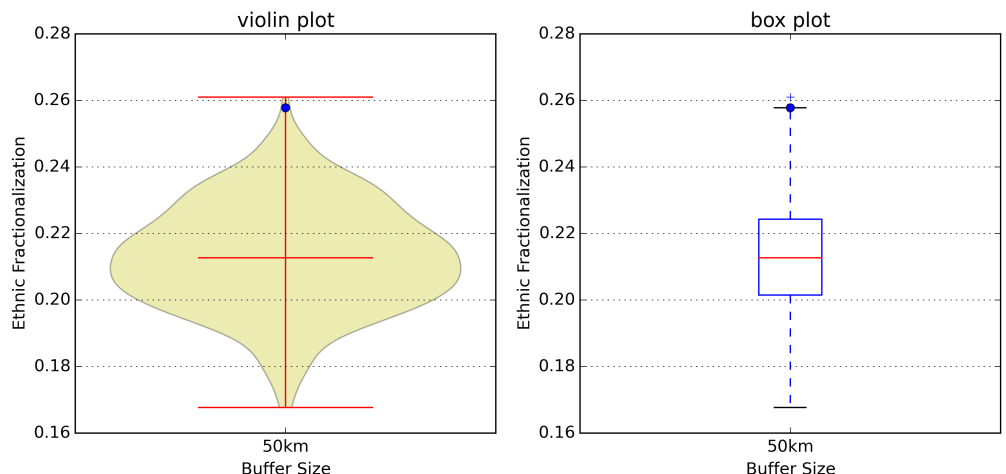

Notes - This graph shows the average Ethnic Diversification Index for the actual location and 500 simulated location market in Sub-Saharan Africa. In each simulation, we randomly generated the location of 224 markets, which are the number of actual number markets located in Africa by Porteous (2015). Then, we create a $50 \mathrm{~km}$ buffer around each market (or simulated market) and estimate the Ethnic Diversity Index. The overall Ethnic Diversity Index mean is 0.212 (actual market $=.237$ - located at 100 percentile) 
FIGURE VIII

Market Location and Growth - Simulation
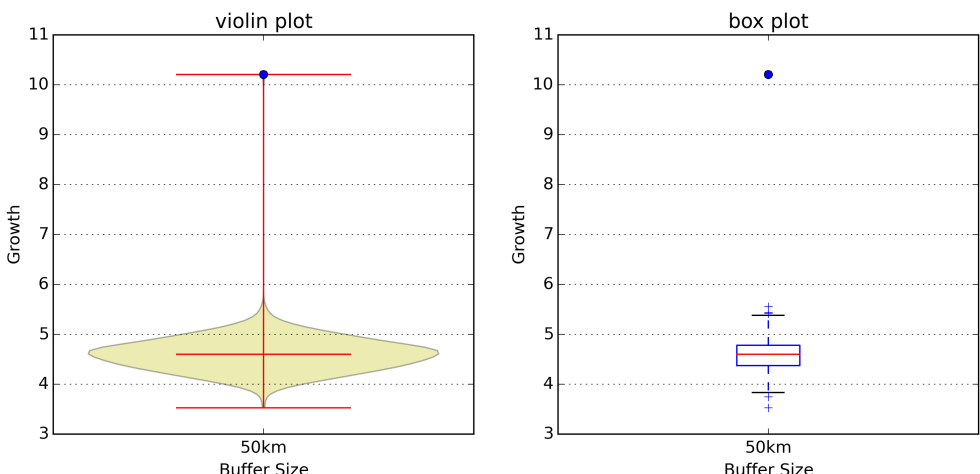

Growth for the actual location and 500 simulated location markets in Sub-Saharan Africa. In each simulation, we randomly generated the location of 224 markets, which are the number of actual number markets located in Africa by Porteous (2015). Then, we create a $50 \mathrm{~km}$ buffer around each market (or simulated market) and Growth. The overall Growth mean is 4.59 (actual market $=10.20-$ located at 100 percentiles) 


\section{DiAGRAM I}

Ethnic Distribution in a Country Cell in Cameroon

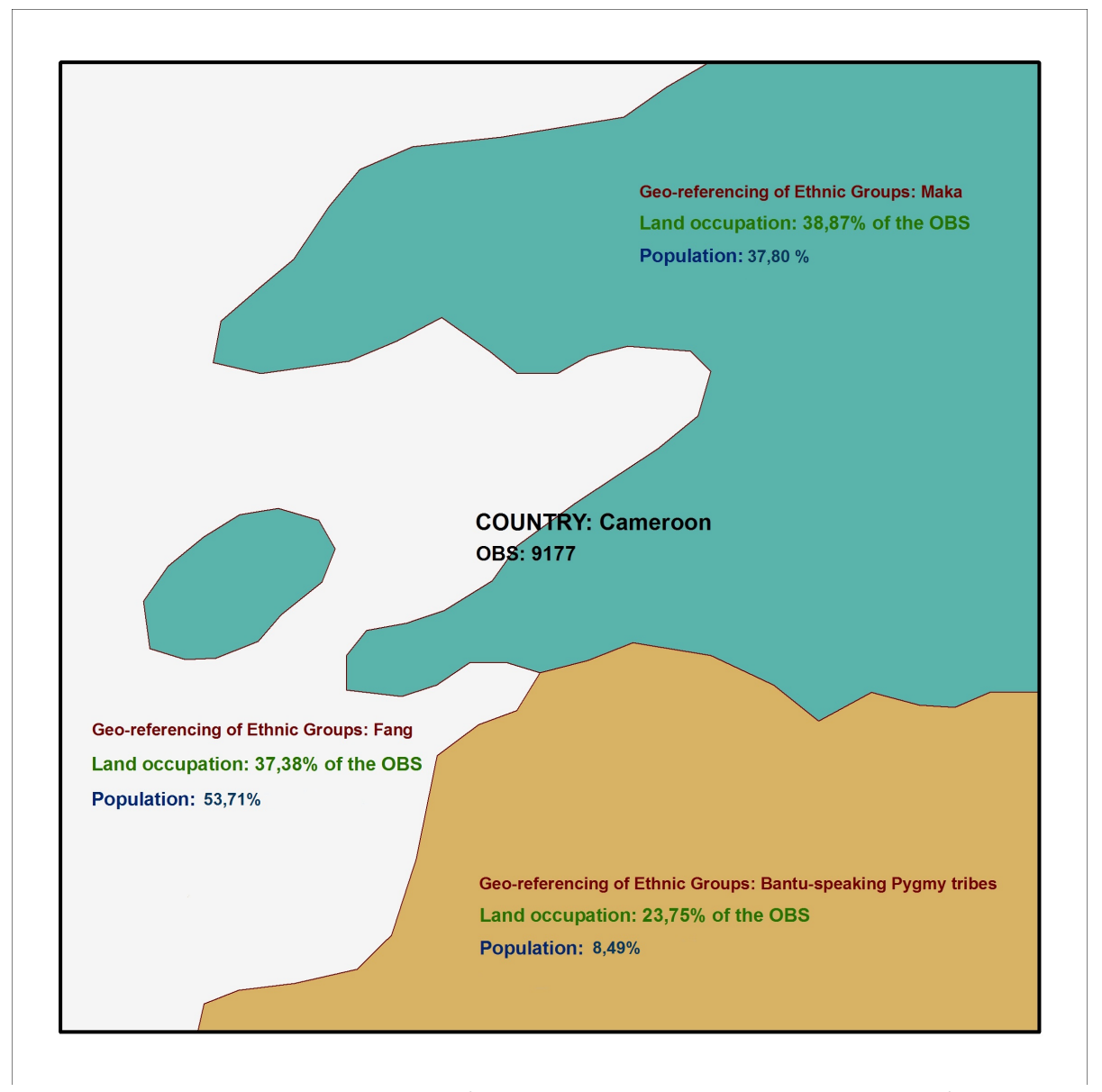

Notes - This Diagram shows the distribution of ethnic groups in a particular cell as an example of the internal structure of any observation 
DIAGRAM II

Ethnic Distribution around de Gambela market

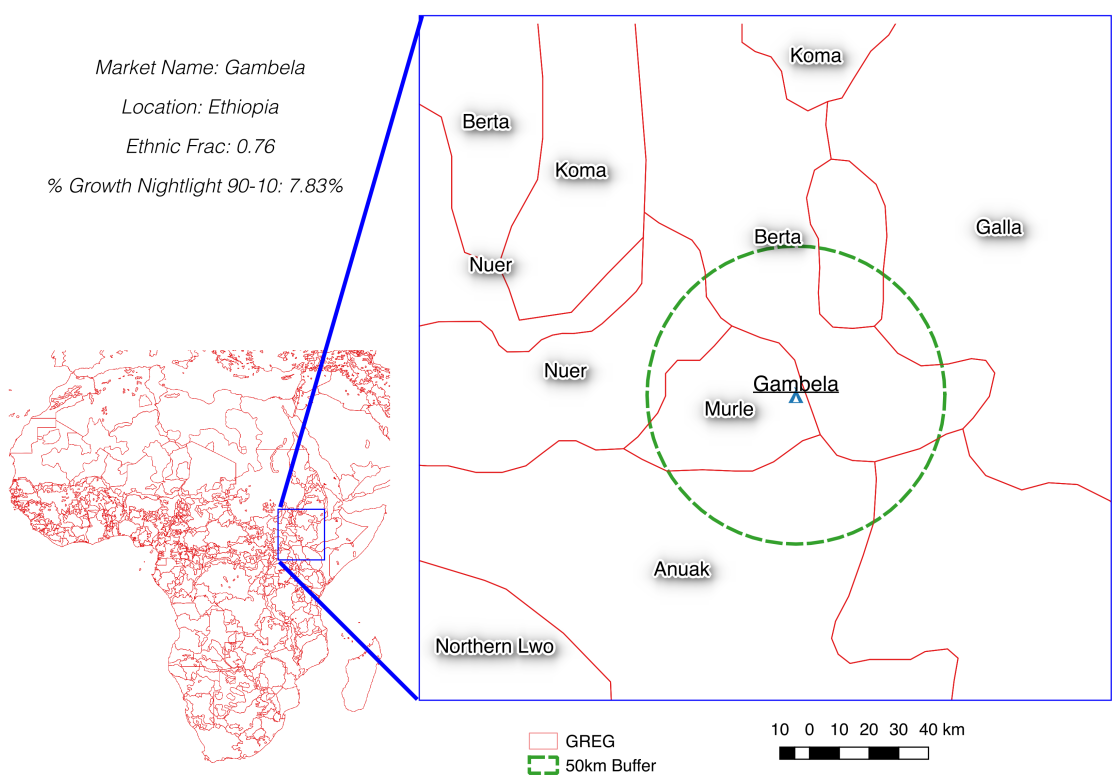

Notes - This Diagram shows the distribution of ethnic groups around a particular market (in this example the Gambela market) 